\title{
Kentsel Alanda Çocuk ve Çocuk Oyun Alanları: Giresun Merkez İlçe Örneğinde Bir Araştırma
}

DOI: 10.26466/opus.692731

*

\author{
Levent Memis* - Sila Gülcan ** \\ *Dr. Öğr. Üyesi, Giresun Üniversitesi, İiBF, Giresun/Türkiye \\ E-Posta: levent memis@hotmail.com \\ ORCID: 0000-0002-5438-691X \\ **Y. L. Öğrencisi, Giresun Üniversitesi, SBE, Çocuk Hakları Anabilim Dalı, Giresun / Türkiye \\ E-Posta: silag276@gmail.com \\ ORCID: 0000-0002-3413-1434
}

\section{Öz}

Bu araştırmada, çocuk oyun alanları üzerinden yerel politikalarda çocuğun ne düzeyde karşılık bulduğu incelenmektedir. Araştırmanın kapsamın Giresun merkez ilçede bulunan 28 mahalle oluşturmaktadır. Kapsam dâhilinde ilçede yer alan çocukların \%70'nin yaşadı̆̆ 8 mahallede bulunan 37 adet oyun alanı, nitel araştırma yöntemleri aracılığıyla inceleme konusu yapılmaktadır. Araştırmada, mahalle bazlı 0-14 yaş çocuk verileri TUI'K'ten ve mahallelerde yer alan oyun parklarının bilgileri ise Giresun Belediyesi'nden elde edilmiştir. Diğer taraftan oyun alanlarının ve elemanlarının niceliksel ve niteliksel durumunun elde edilmesi için ise formdan yararlanılmıştır. Araştırmada elde edilen sonuçlara göre, kentleşmesini sürdüren yeni olarak nitelendirilecek mahallelerde, oyun alanı miktarının artığ̀ , çocuk başına düşen alanın 9.3 ile $1.5 \mathrm{~m}^{2}$ arasında değişkenlik gösterdiği, fakat oyun alanının bulunmadığı mahallerin varlığı tespit edilmektedir. Oyun alanlarının fonksiyonelliği, bakımı ve güvenliği açısından "orta" düzeyde bir durumun olduğu; oyun elemanları açısından kaydırak ve salıncağın öne çıktığı ve çocuklar arasında etkileşime aracı olabilecek geleneksel oyunların yer almadı̆̆g görülmektedir.

Anahtar Kelimeler: Çocuk Hakkı, Kentli Hakkı, Çocuk Oyun Alanları, Belediye, Çocuk Dostu Kent 


\title{
Children and Playgrounds in the Urban Area: A Study in the Case of Giresun Central District
}

\begin{abstract}
In this study, the level of response of the child in local policies through the playgrounds is examined. The scope of the research consists of 28 neighborhoods located in the central district of Giresun. Within the scope of the study, 37 playgrounds in 8 neighborhoods where $70 \%$ of the children in the district live are subject to examination through qualitative research methods. In the study, neighborhoodbased child data was obtained from TUIK (Turkish Statistical Institute) and information of the playgrounds in the neighborhoods were obtained from Giresun Municipality. On the other hand, in order to obtain the quantitative and qualitative status of the playgrounds and its elements, the form was used. According to the results obtained in the research, the amount of playgrounds increased with the increasing population in the neighborhoods that will be described as new urbanization, the area per child varies between 9.3 and $1.5 \mathrm{~m}^{2}$ however, the presence of the areas where the playground is not available is determined. There is a "medium" level in terms of functionality, maintenance and safety of playgrounds; In terms of play elements, it is seen that slide and swing is more preferred than traditional games that interact with between the children.
\end{abstract}

Keywords: Children's Right, Urban Right, Children Playgrounds, Municipality, Child Friendly City 


\section{Giriş}

Yaşamın belirli bir evresine çocukluk, bu evrede bulunanlar da çocuk olarak nitelendirilmektedir. Çocukluk evresi, farklı şekillerde ele alınmakla birlikte, genel olarak 0-18 yaş aralığı olarak kabul görmektedir. Hatta bahsi edilen süreç kendi içinde alt evrelere (0-3, 4-6, 7-15 yaş gibi) ayrılmakta ve bu evreler içinde bulunan çocukların fizyolojik ve biyolojik ihtiyaçları farklılaşmaktadır. Bu gelişim sürecinde çocuğun en önemli araçlarından biri de oyun ve oyuncaklardır. Bu araçlar bedensel ve zihinsel gelişimine katkı sağladığ gibi sosyal gelişimi açısından da önemli bulunmaktadır. Çocuğun dış baskıya maruz kalmadan kendi isteğiyle giriştiği tüm etkinliklerin karşıllğı olan oyun, çocukların fizyolojik ihtiyaçlarından sonra ikinci derecede gündeme gelen bir ihtiyaçtır (Çakırer-Özservet, 2018a,s.91). Erken yaşlardan itibaren oyunların araçsal konumu, çocukların sosyalleşmesi, gelişimi ve öğrenmesine katkılar sağlarken, bu sayede çocukların sağlıklı ve başarılı bireyler haline gelmesinde çok önemli role sahip olmaktadır.Ayrıca belirtmek gerekir ki, oyun sadece çocuğun yaşamına dahil olan bir araç değildir. Oyun, farklı türleriyle (dijital veya manuel) yetişkinlerin boş zaman faaliyeti, eğitimin bir parçası veya kent yönetimine katılımın bir aracı olabilmektedir (bkz. Tan, 2019). 2019 verilerine göre Türkiye'de 0-14 grubunda 19.212.345 çocuk bulunmaktadır. Yani nüfusun (83.154.997) \% 23,1 çocuklardan oluşmaktadır.

Oyun açıcından da büyük oranda çocukların da yaşamlarının karşlık bulduğu kentsel alanlar önem kazanmaktadır. Kentler; kadın, yaşlı, engelli, zengin, yoksul gibi tarafların beklentilerine cevap vermesi gerektiği gibi, daha iyi yaşam kalitesine ulaşma açısından çocukların gereksinimlerine de cevap vermesi gerekmektedir. Bu bağlamda çocukların kendilerini sosyal olarak gerçekleştirebilecekleri alanlar oyun parklarıdır. Özellikle kamusal alanda karşlık bulan işlevsel, korunaklı ve güvenli biçimde dizayn edilmiş oyun parkları önem arz etmektedir. Aksi durumda çocuğun isteğine karşılık gelmeyen, fiziki koşullarının iyi olmadığı ve kullanılmayan oyun parklarının potansiyel tehlike olduğu yadsınamaz gerçektir. Bu noktada kentsel alanın yönetiminde birinci derecede sorumlu kılınan belediyelere önemli görevler düşmektedir.

İfade edilenler bağlamında çalışmanın temel amacı, çocuk oyun alanları üzerinden yerel politikada çocuğun ne düzeyde karş1lık bulduğunu incele- 
mektir. Bu inceleme Giresun merkez ilçe kapsamında, mahalle bazında oyun alanlarının yeterliliği bağlamında niceliksel ve oyun alanlarında yer alan oyun elemanları bağlamında niteliksel açılardan gerçekleştirilmektedir. Mahalle bazında çocuk nüfusunun elde edilmesinde TUIK'den, ilgili kapsamdaki mahallelerin çocuk oyun alanlarıyla ilgili niceliksel bilgilerin elde edilmesinde Giresun Belediyesi'nden, oyun elemanlarının niteliksel durumu için ise ilgili literatürden hareketle geliştirilen "Çocuk Oyun Alanları Veri Elde Etme Formu'ndan yararlanılmıştır.

\section{Kentin Bir Paydaşı Olarak Çocuk, Oyun-Oyun Alanları ve Belediye}

Yetişkinlerin bulunduğu mekâna bağlı olarak çocukların da yaşamlarının gerçekleştirdiği temel yaşam alanı kentlerdir. Bu açıdan, çocuklar kentlerin önemli bir paydasını oluşturmakta ve üretilen kentsel politikaların bir parçası haline dönüşmektedir. Hatta çocuklar, sahip oldukları özellikleri itibariyle kentin bir tarafı olarak çeşitli haklarla donatılmaktadır.

Tarihsel sürece bakıldığında ise çocukluğun ve çocuğun uzunca bir süre ayrıca dikkate alınmadığı ifade edilmektedir (Işıkçı, 2019: 3). Bu durumu iyileştirecek çeşitli çabalar gösterilmekle birlikte çocuğu odağına alan en önemli gelişme, 14 Eylül 1990 tarihinde yürürlük kazanan "Çocuk Haklar1na Dair Birleşmiş Milletler Sözleşmesi" dir. Üç Kısım ve 54 maddeden oluşan Sözleşme, çeşitli açlardan [dinlenme, boş zaman değerlendirme, oynama ve yaşına uygun eğlence (etkinliklerinde) bulunma ve kültürel ve sanatsal yaşama serbestçe katılma] çocuk haklarını öne çıkarmaktadır. Bu haklardan biri de oyunla ilişkilidir. Çocuk, yaşı ve doğası gereği oyun oynama ihtiyacı duymaktadır. Çünkü oyun, fiziksel (sindirim, solunum, dolaşım vb.) ve sosyal (çevreyi tanıma, iletişim kurma gibi) yönden birçok işlevi barındırmaktadır (Ballığlu, 2015: 9). Bu noktada oyun, insanlık tarihi kadar eski olmakta, farklı kültürlerin kendine özgü oyun ve oyuncak türleri bulunmaktadır (bir örnek için bkz. Gürbüz, 2017). Sözleşme'nin 31. Maddesinin ilk bölümünde: "Taraf Devletler çocuğun dinlenme, boş zaman değerlendirme, oynama ve yaşına uygun eğlence (etkinliklerinde) bulunma ve kültürel ve sanatsal yaşama serbestçe katılma hakkın tanırlar" şeklinde bir düzenlemeye yer verilmiştir.

Diğer taraftan kentli hakları bağlamında da gündeme gelen bazı belgelerde, ayrı bir taraf olarak çocuğa vurgu yapılmaktadır. Bu noktada kentin 
bir parçası olarak çocuğun hakları ile kentli hakları bir biriyle örtüşmektedir (Akkoyunlu Ertan, 2014,s.99-100). En genel ifadesiyle kent hakk1, mekanın kent olmasından kaynaklı ortaya çıkan potansiyel imkanlardan, kentte yaşayan insanların/tarafların ihtiyaç duyduğu ölçüde yararlanması ve imkanların yaratılmasında tarafların söz sahibi olmasına dayanmaktadır. Diğer bir ifadeyle kentli hakları bağlamında kentte bulunan herkes, temiz ve sağlıklı bir kentte yaşama, yeterli kamu hizmetlerini alma ve her türlü ihtiyaçlarının karşılanması hakkına sahiptir. Bu anlamda kapsamı oldukça geniştir (Karasu, 2009,s.9; 12). Kentli haklarının somut biçimde ilk kez ortaya konulduğu Kentsel Şart -I'de yer verilen haklardan biri de, her bireyin spor yapabileceği ve boş zamanlarını değerlendirebileceği alanların oluşturulmasıdır. Ayrıca Şart'da oyun alanlarının da dahil olduğu açık alanların kentin yapıları kadar önemli olduğu vurgusu yapılmaktadır (Akt. Mutlu, 2010,s.128; 281282)

Çocuklar açısından en temel politika unsuru ise, birçok açıdan çocuğun yaşamında etkisi olan oyun alanlarıdır. Bu alanlar çocukların karşılaştı̆̆ı, etkileşim kurduğu, bedensel aktivitelerin gerçekleştiği temel mekânlardır. Belirtilen öneme bağlı olarak alanın niceliğine yönelik bazı kriterlerin getirildiği görülmektedir. Örneğin Almanya'da oyun ve çocuk bahçeleri için kişi başına 0.5-2.4 m², Avustralya'da (5.000 kişilik mahalle ölçeğini dikkate alarak) $4.6 \mathrm{~m}^{2}$, Fransa' da 5m², İngiltere' de $24 \mathrm{~m}^{2}$ olarak belirlenmiştir (Akt. Yılmaz ve Bulut, 2002,s.346). Yine nicelik açısından çocuk başına oyun alanının $6 \mathrm{~m}^{2}, 5-7 \mathrm{~m}^{2}, 4 \mathrm{~m}^{2}$ gibi olması gerektiği yönünde görüşler bulunmaktadır (Akt. Yeşil ve Beyli, 2018,s.653). Türkiye'de ise Plan Yapımına Ait Esaslara Dair Yönetmelikte, park, çocuk bahçesi, oyun alanları olarak ayrılan alanlar "aktif yeşil alan" olarak nitelendirilmekte ve kişi başına asgari $10 \mathrm{~m}^{2}$ olarak belirlenmektedir (Şimşek, 2010,s.171). Bu aktif yeşil alanın dağılımı ise; kişi başına $1.5 \mathrm{~m}^{2}$ çocuk oyun alanı, $2 \mathrm{~m}^{2}$ mahalle ve semt parkı, $3,5 \mathrm{~m}^{2}$ kent parkı ve $3 \mathrm{~m}^{2}$ spor alanları olarak yapılmaktadır (Akt. Demir, Aydemir ve Önem, 2015,s.273).

Çocukların yaşam evresi içinde oyunun, oyun elemanlarının ve oyun alanlarının işlevleri değişkenlik göstermektedir. Erkartal (2015: 99), Gür ve Zorlu (2002)'den hareketle çocuk oyun türlerini beden hareketinin yoğunluğu ve kurgulanma biçimine göre ikiye ayırmaktadır. Bu oyunlarda kendi içinde, beden hareketlerinin yoğunluğuna göre aktif ve pasif şeklinde; kurgulanma biçimine göre ise yaratıcı, düşsel, bilişsel ve eğitsel biçimde sınıf- 
landırılmaktadır. Bu nedenle farklı yaş gruplarına karşılık gelecek araçların ve alanların kullanımı önemli bulunmaktadır. Farklı yaş grupları dikkate alınarak yapılan bir sınıflandırmaya göre oyun mekanları; sabit olmayan malzemelerin, kum havuzlarının, oyun evlerinin, oyun heykelleri gibi unsurların bulunduğu oyun bahçeleri (3-6 arası yaş), salıncak, kaydırak ve diğer elemanların yer aldığı, serbest etkinlik ve spor alanlarının bulunduğu oyun alanları (5-16 arası yaş) ve spor kortların, yüzme komplekslerinin, kültürel ve sanatsal etkinlik alanlarının bulunduğu oyun arsaları (13-19 arası yaş) şeklinde belirtilmektedir (Yılmaz ve Bulut, 2002,s.347-348).

İfade edilenler çerçevesinde iyi bir oyun parkı için aşağıda yer verilen kriterler öne çıkarılmaktadır (İstanbul 95, 2018,s.3):

- Konum-Ulaşılabilirlik: Çocuğun bulunduğu yerleşim alanına yakınlığı ve ulaşılabilirliği.

- Yaş grubuna uygunluk: Oyun elemanlarının, farklı yaş gruplarının özellik ve ihtiyaçlarına karşılık gelmesi.

- Temel ihtiyaçların karşılanması: Çocukların ve onlara eşlik eden kişilerin temel ihtiyaçlarını karşılayacak donanımların varlığı.

- Güvenlik: Hem oyun elemanlarının hem de genel olarak oyun alanının risklerden arındırılarak güvenli hale getirilmesi.

- Kapsayıcılık: Oyun alanının ve elemanlarının, çocuk topluluğu içinde farklı özellikleriyle yer alan taraflara karşılık gelme durumu.

- Özgünlük: Yerleşim alanının kültürüne ve doğal şartlarına uygunluk.

- Davetkâr ortam: Oyun elamanlarının ve oyun alanının teşvik edici şekilde düzenlenmesi.

- Doğayla olan ilişkisi: Doğal donatılarla (çimen, su, kum, ağaç gibi) bütünleşik bir alanı yansıtması.

- Esneklik: Sabit donatıların dışında, değiştirilebilir, taşınabilir ve farklı şekillerde değerlendirilebilir malzemelerin bulunması.

- Risk alma ve deneme: Çocukların kapasite ve yeterliliklerini değerlendirebilecekleri alanların bulunması.

- Oyun çeşitliliği: Farklı açılardan çocukların gelişimine katkı sunacak oyun çeşitliliğinin bulunması.

Oyun alanlarına yönelik politikaların geliştirilmesi konusunda, Türkiye'de kentsel alanda temel aktör belediyelerdir. 5393 sayılı Belediye Kanunu'nun 14. Maddesinde, mahalli müşterek nitelikte olmak şartiyla hangi hizmetlerin belediyeler tarafından yerine getirileceği sıralanmaktadır. $\mathrm{Bu}$ 
hizmetler arasında, çocuk oyun alanları şeklinde ayrıca belirtilmemekle birlikte, park ve yeşil alanlar da belediyelerin görev ve sorumluluklarına bırakılmaktadır. Dolayısıyla belediyeler, öncesinde belirtilen kriterler bağlamında, öncelikle çocuğun yaşadığı mahalleyi baz alarak, ihtiyaç duyulan miktarda ve nitelikte oyun alanı oluşturmak ve bakımını yerine getirmekle yetkilidir.

\section{Araştırmanın Amacı, Önemi ve Kapsamı}

Araştırmanın temel amacı, çocuk oyun alanları üzerinden yerel politikada çocuğun ne düzeyde karşılık bulduğunu incelemektir. Ayrıca bu araştırmada, Giresun Belediyesi'nin de yer aldığı, 2014-2015 yılları arasında UNICEF önceliğinde gerçekleştirilen "Çocuk Dostu Kent" projesinin, oyun alanlarına olan etkisini irdelemek amacı güdülmektedir.

Giresun merkez ilçe özelinde, genel olarak açık yeşil alanlara yönelik bir araştırma bulunmaktadır (bkz. Koç, 2019). Bu çalışmada ise detayda, yeşil alanların bir alt bileşeni olan çocuk oyun alanlarına odaklanılmaktadır. $\mathrm{Bu}$ durum çalışmanın önemini vurgulamaktadır.

Araştırmanın kapsamını Giresun merkez ilçe oluşturmaktadır. TUİ'in 2019 verilerine göre Giresun il nüfusu 448.400'dir. Giresun'un 16 ilçesi bulunmakta, bu ilçeler arasında en fazla nüfusa sahip yerleşim yeri 135.920 kişiyle merkez ilçedir. Bu nüfusun 7.948'i 0-4, 8.418'i 10-14 yaş aralığında bulunan çocuklardan oluşmaktadır. Toplamda da 16.366 0-14 yaş aralığında çocuk bulunmaktadır. Giresun Belediyesi'nin hizmet sunduğu sınırları içinde Tablo 1'de yer verildiği üzere 28 mahalle bulunmaktadır. Ayrıca dört yerleşim (Uzgur, Alınca, Barça ve Güney Köy) yerinden oluşan mücavir alanı yer almaktadır. 
Tablo 1. Mahallerin Çocuk Durumu

\begin{tabular}{|c|c|c|c|}
\hline Mahalleler & Mahallenin Nüfusu & 0-14 Çocuk Sayısı (2019) & Çocuk Oranı (\%) \\
\hline Aksu Mahallesi & 8.831 & 1.992 & 0,23 \\
\hline Çınarlar Mahallesi & 3.372 & 638 & 0,19 \\
\hline Çıtlakkale Mahallesi & 11.708 & 2.458 & 0,21 \\
\hline Fevzi Çakmak Mahallesi & 4.143 & 906 & 0,22 \\
\hline Gaziler Mahallesi & 5.018 & 467 & 0,09 \\
\hline Gedikkaya Mahallesi & 12.310 & 2.840 & 0,23 \\
\hline Gemilerçekeği Mahallesi & 7.804 & 1.436 & 0,18 \\
\hline Güre Mahallesi & 2.858 & 338 & 0,12 \\
\hline Hacı Hüseyin Mahallesi & 6.570 & 1.328 & 0,20 \\
\hline Hacı Miktad Mahallesi & 2.473 & 433 & 0,17 \\
\hline Hacı Siyam Mahallesi & 9.539 & 1.616 & 0,17 \\
\hline Kale Mahallesi & 2.109 & 300 & 0,14 \\
\hline Kapu Mahallesi & 1.361 & 293 & 0,22 \\
\hline Kavaklar Mahallesi & 6.597 & 1.186 & 0,18 \\
\hline Nizamiye Mahallesi & 4.323 & 866 & 0,20 \\
\hline Osmaniye Mahallesi & 3.605 & 653 & 0,18 \\
\hline Seldeğirmeni Mahallesi & 2.705 & 592 & 0,22 \\
\hline Şeyhkeramettin Mahallesi & 813 & 128 & 0,16 \\
\hline Teyyaredüzü Mahallesi & 14.757 & 3.053 & 0,21 \\
\hline Erikliman Mahallesi & 2.026 & 416 & 0,21 \\
\hline Kayadibi Mahallesi & 1.025 & 121 & 0,12 \\
\hline Küçükköy Mahallesi & 863 & 162 & 0,19 \\
\hline Çaykara Mahallesi & 1.141 & 202 & 0,18 \\
\hline Aydınlar Mahallesi & 638 & 140 & 0,22 \\
\hline Cumhuriyet Mahallesi & 289 & 171 & 0,06 \\
\hline Yalı Mahallesi & 361 & 39 & 0,11 \\
\hline Sultan Selim Mahallesi & 411 & 71 & 0,17 \\
\hline Toplam & 117.650 & 22.691 & 0,19 \\
\hline
\end{tabular}

Kaynak: TUIK, 2019; Giresun Belediyesi Kent Rehberi, http://keos.giresun.bel.tr:85/keos/

\section{Araştırmanın Yöntemi}

Çocuk oyun alanlarıyla ilgili önemli bir literatürün ortaya çktığ görülmektedir. Gerçekleştirilen araştırmalar incelendiğinde anket gibi bazı nicel yöntemlere başvurulmakla birlikte, büyük oranda nitel yöntem bağlamında araştırmaların yapıldığı anlaşılmaktadır. Nitel yöntem arasından ise oyun alanlarının niteliğini ortaya çıkarmaya çalışan hem çocuklara hem de ebeveynlerine yönelik mülakatlar (Jansson, 2008) ve oyun alanlarında verilerin elde edilmesini sağlayan bir form üzerinden yerinde gözlem öne çımmakta-

\footnotetext{
${ }^{1}$ 0-6 yaş grubu 15'den kücük olduğu için verisi bulunmamaktadır.
} 
dır. Bu araştırmada da, ilgili literatürden hareketle, öncelikle Giresun merkez özelinde çocuk oyun alanlarının niceliksel durumu ortaya çıkarılmakta ve hazırlanan bir form üzerinden niteliksel durumu inceleme konusu yapılmaktadır. Ayrıca gerçekleştirilen araştırmalar incelendiğinde çocuk oyun alanlarının peyzaj mimarlığı, okul öncesi eğitimi, çocuk gelişimi, şehir ve bölge planlama, beden eğitimi gibi bilim alanları kapsamında inceleme konusu yapıldığı anlaşılmaktadır. Bu çalışmada çocuk oyun alanlarına, yerel yönetim politikalarının aracı bir unsuru olarak odaklanılmaktadır. Bu bağlamda niceliksel bir durum tespiti yapılmakta ve oyun alanlarının niteliği belirlenen kriterler üzerinden incelenmektedir².

İlgili araştırmalarda kriterlerin farklı şekilde belirlendiği ve uygulandığı (bkz. Duman ve Koçak, 2013; Ermiyagil ve Gürçınar, 2015; Başaran Uysal, 2015) görülmektedir. Bu çalışmada yapılan yaş sınıflandırmasına göre fonksiyonellik, güvenlik ve bakım kriterleri, aşağıda tabloda yer verildiği şekilde dikkate alınmaktadır. Ayrıca oyun elemanı ve zemin malzemeleri dikkate alınmaktadır. Diğer taraftan oyun parkını tamamlayıcı unsurlar (çeşme, gölgelendirme, tuvalet, çocuk bakım mekanı, oturma bankı, bisiklet yolu, yürüyüş yolu, aydınlatma, çöp kutusu, bitkilendirme, konum, bedensel engellilere uyumluluğu gibi) da dikkate alınmaktadır. İfade edilenler çerçevesinde hazırlanan form aracilığıyla çocuk sayısıyla öne çıkan ve ilçe yerleşim alanında bulunan, çocukların \%70'ini barındıran Aksu, Çıtlakkale, Gedikkaya, Gemilerçekeği, Hacı Hüseyin, Hacı Siyam, Kavaklar ve Teyyaredüzü Mahalleleri'nde yerinde inceleme yapılmaktadır. Ayrıca 2012'den bu yana Giresun Belediyesi Çocuk Birimi Koordinatörü ile 20. 02. 2020 tarihinde ortalama $30 \mathrm{dk}$. süren yarı yapılandırılmış bir mülakat gerçekleştirilmiştir.

\footnotetext{
${ }^{2}$ Veri elde etme formu hazırlanırken ilgili şu kaynaklardan yararlanılmıştır: Çoşkun, 2015; Ermiyagil ve Gürçınar, 2015, Özalp vd., 2012, Samur ve KIzıltepe, 2018; Türkan ve Önder, 2011; Türkan, 2009; Pepe ve Kazan Kırçık, 2005; Yılmaz ve Bulut, 2002; Akkülah ve Güngör, 2009; Aklıbaşında, Tırnakçı ve Özhancı, 2018; Bahtiyar Karadeniz, 2016; Uysal, 2014; Koçan ve Çorbacı, ?; Çetin, 2003; Kuşuluoğlu, 2013.
} 
Tablo 2. Oyun Elemanlarının Fonksiyonelliği, Güvenliği ve Bakımı Değerlendirme Kriterleri

Fonksiyonellik Hiç: Oyun alanı yaş gruplarına göre tasarlanmamış, oyun alanları arasında yeterli mesafenin bulunmayışı ve tamamlayıc donatıların uygun yerlerde bulunmayışı. Az: Oyun alan yaş gruplarına göre tasarlanmamış, oyun alanları arasında yeterli mesafe bulunmakta ve tamamlayıc donatıların uygun yerlerde bulunmayışı.

Orta: Oyun alan yaş gruplarına göre tasarlanmamış, oyun alanları arasında yeterli mesafe bulunmakta ve tamamlayıc donatılar uygun yerlerde bulunmakta

Çok: Oyun alanı yaş gruplarına göre tasarlanmış, oyun alanları arasında yeterli mesafe bulunmakta ve tamamlayıcı donatılar uygun yerlerde bulunmakta

Güvenlik Hiç: Parkın etrafı kuşatmayla çevrili değil, oyun elamanları bakımlı değil ve olması

(malzeme güvenliği gereken güvenlik uygulamaları bulunmamakta (salıncak koruması yok, kaydırağın ve genel olarak merdiveni uygun değil, kaydırağın zemini aşınmış vb.)

alanın güvenliği) Az: Parkın etrafında kuşatma bulunmakta fakat araç yoluna çıkan kapılar açık, oyun elamanları bakımlı değil.

Orta: Parkın etrafında kuşatma bulunmakta fakat araç yoluna çıkan kapılar açık; oyun elamanları bakımlı.

Çok: Parkın etrafında kuşatma bulunmakta, araç yoluna çıkan kapılar kapalı ve oyun elamanları bakıml.

Bakım

Hiç: Oyun elemanlarının tamamına yakını kullanılmayacak durumda.

Az: Oyun elemanlarını bir kısmı kullanilabilir durumda

Orta: Oyun elemanları kullanılabilir durumda fakat boyasız, eklem yerleri bakılmamış, paslı veya kırık durumda

Çok: Oyun elemanlarının tamamı kullanılmakta ve bakımları yapılmış durumda

\section{Araştırmanın Bulguları}

\section{Oyun Alanlarının Mekânsal Görünümü}

Araştırmanın odağını 8 mahalle oluşturmaktadır. Giresun il merkezinde bulunan çocukların \%70'i, ifade edilen mahallelerde yaşamaktadır. Bu mahallerin üçü (Hacı Siyam, Hacı Hüseyin ve Gemilerçekeği Mah.) eski yerleşim alanlarıdır. Diğer mahalleler son yıllarda inşa edilen konutlarla birlikte öne çıkmaya başlayan yeni yerleşim alanlarına karşılık gelmektedir. İfade edilen yerleşim yerleri arasında çocuk oyun alanları açısından, yeni yerleşim alanlarının daha fazla plan odaklı olmasına rağmen çok büyük farklılıklar bulunmadığı görülmektedir. Oyun mekanı açısından miktarın artmasında en önemli etken, İl Özel İdaresi'nin yapımını ve sonrasında Giresun Belediyesi'ne devrini gerçekleştirdiği dolgu alanlarıdır.

Miktar açısından odaklanıldığında, öncesinde de yer verildiği üzere Türkiye'de çocuk başına $10 \mathrm{~m}^{2}$ lik aktif yeşil alan (park, bahçe, oyun alanları) öngörülmektedir. Sadece oyun alanları dikkate alındığında ise her bir çocuk için 1,5 m²'lik alanın olması gerekliliği öne çıarılmaktadır. 
Kentsel Alanda Çocuk ve Çocuk Oyun Alanları: Giresun Merkez İlçe Örneğinde Bir Araştırma

Tablo 3. Oyun Alanlarnın Mekânsal Durumu

\begin{tabular}{|c|c|c|c|c|c|c|}
\hline $\begin{array}{l}\text { Mahalleler ve } \\
\text { Kapladığı Alan }\left(\mathrm{m}^{2) 3}\right. \\
\end{array}$ & Kuruluş & Parklar & Parkların Alanı & $\begin{array}{l}\text { Toplam } \\
\text { Alan }\left(\mathrm{m}^{2}\right) \\
\end{array}$ & $\begin{array}{l}\text { 0-14 Yaş } \\
\text { Çocuk }\end{array}$ & $\begin{array}{l}\text { Çocuk Başına } \\
\text { Düşen Miktar (m²) }\end{array}$ \\
\hline \multirow{4}{*}{$\begin{array}{l}\text { Aksu / } \\
3.660 .019\end{array}$} & & Abacıbükü Parkı & 561 & \multirow[b]{4}{*}{5.009} & \multirow[b]{4}{*}{1.992} & \multirow[b]{4}{*}{2.5} \\
\hline & & Hayrettin Erkmen Çocuk Parkı & 2.612 & & & \\
\hline & 2018 & Aksu Mahallesi Konakyanı Sok. Çocuk Parkı & 1.020 & & & \\
\hline & & Deniz Sitesi Parkı & 816 & & & \\
\hline \multirow{4}{*}{$\begin{array}{l}\text { Çınarlar / } \\
84.209\end{array}$} & & Çınarlar Mah. Kaymak Sok. Çocuk Parkı & 1.040 & \multirow{4}{*}{1.466} & \multirow[b]{3}{*}{638} & \multirow[b]{3}{*}{2.3} \\
\hline & & Seyidi Vakkas Çocuk Parkı & 116 & & & \\
\hline & & Tepebaşı Parkı & 110 & & & \\
\hline & & Dr. Atsushi Miyazaki Parkı & 200 & & & \\
\hline \multirow{7}{*}{$\begin{array}{l}\text { Çıtlakkale / } \\
2.832 .205\end{array}$} & 2014 & Çıtlakkale Mah. Sönmez Sokak Çocuk Parkı & 410 & \multirow[b]{7}{*}{8.107} & \multirow[b]{7}{*}{2.458} & \multirow[b]{7}{*}{3.3} \\
\hline & 2019 & Çıtlakkale Mah. 121. Nolu Sokak Çocuk P. & 1.450 & & & \\
\hline & & Soyer Sitesi Çocuk Parkı & 571 & & & \\
\hline & & Sözmez Caddesi Çocuk Parkı & 1.805 & & & \\
\hline & & Barış Manço Parkı & 3.551 & & & \\
\hline & & 26 Evler Üstü Çocuk Parkı & 260 & & & \\
\hline & & 26 Evler Çocuk Parkı & 60 & & & \\
\hline Fevzi Çakmak /356.294 & 2014 & Yeni Mahalle Çocuk Parkı & 1.020 & 1.020 & 906 & 1.1 \\
\hline \multirow[t]{2}{*}{ Gaziler / 1.243.694 } & 2011 & Gaziler Mahallesi Çocuk Parkı & 1.175 & \multirow[b]{2}{*}{1.405} & \multirow[b]{2}{*}{467} & \multirow[b]{2}{*}{3} \\
\hline & & Gaziler Tepesi Çocuk Parkı & 230 & & & \\
\hline \multirow{5}{*}{$\begin{array}{l}\text { Gedikkaya / } \\
1.932 .321\end{array}$} & 2015 & Derya Sayın Çocuk Parkı & 510 & \multirow[t]{5}{*}{4.306} & \multirow[t]{5}{*}{2.840} & \multirow[t]{5}{*}{1.5} \\
\hline & 2015 & Nihal Şen Çocuk Parkı & 1.350 & & & \\
\hline & 2018 & Gedikkaya Mah. Nihatbey Cad. Çocuk Parkı & 970 & & & \\
\hline & 2019 & Tez-Koop Sitesi Çocuk Parkı & 695 & & & \\
\hline & & Polis Lojmanları Parkı & 781 & & & \\
\hline \multirow{3}{*}{$\begin{array}{l}\text { Gemilerçekeği / } \\
439.077\end{array}$} & 2011 & Mustafa Aydınay Parkı & 657 & \multirow{3}{*}{2.501} & \multirow{3}{*}{1.436} & \multirow{3}{*}{1.7} \\
\hline & & Tozlu Sokak Çocuk Parkı & 220 & & & \\
\hline & 2018 & Botanik Bahçe $^{4}$ & 1.000 & & & \\
\hline
\end{tabular}

${ }^{3}$ Mahallelerin alan bilgileri Giresun Belediyesi tarafından hazırlanan Kent Bilgi Sistemi (http://keos.giresun.bel.tr:85/keos/)’nden alınmıştır.

643 OPUS ㅇ Uluslararası Toplum Araştırmaları Dergisi 
SAGAE Park ${ }^{5}$

\begin{tabular}{|c|c|c|c|c|c|c|}
\hline & & SAGAE Park $1^{5}$ & 624 & & & \\
\hline Güre / 120.820 & & Can Yücel Parkı & 3.168 & 3.168 & 338 & 9.3 \\
\hline \multirow{2}{*}{$\begin{array}{l}\text { Hacı Hüseyin / } \\
276.330\end{array}$} & & 19 Eylül Çocuk Parkı & 1.627 & & & \\
\hline & & 15 Temmuz Spor Kompleksi ${ }^{6}$ & 1.200 & 2.827 & 1.328 & 2.1 \\
\hline \multirow[t]{2}{*}{ Haci Siyam / } & 2011 & İnönü Caddesi Çocuk Parkı & 460 & & & \\
\hline & & Süleymen\&Abdullah Bozbağ Çocuk Parkı & 200 & & & \\
\hline \multirow[t]{2}{*}{405.920} & & Sazbeyi Çocuk Park & 1.773 & & & \\
\hline & 2009 & Cumhuriyet Parki ${ }^{7}$ & 500 & 2.933 & 1.616 & 1.8 \\
\hline Kale / 372.290 & & Kale Mesire Alanı Çocuk Parkı & 500 & 500 & 300 & 1.6 \\
\hline \multirow[t]{3}{*}{ Kavaklar / 4.916.615 } & 2014 & Çotanak Çocuk Parkı & 998 & 2.154 & 1.186 & 1.8 \\
\hline & & Hopcuk Park1 & 500 & & & \\
\hline & & Acar Sitesi Çocuk Parkı & 656 & & & \\
\hline Nizamiye /217.746 & 2014 & Kubilay Güngör Parkı & 730 & 730 & 866 & 0.8 \\
\hline Seldeğirmeni / 2.133.651 & 2019 & Stad Park Evleri Çocuk Parkı & 1.100 & 1.100 & 592 & 1.9 \\
\hline \multirow[t]{2}{*}{ Teyyaradüzü / } & 2009 & Dattara Mehmet Yüksel Parkı & 1.418 & & & \\
\hline & 2011 & Mollaoğlu Sokak Çocuk Parkı & 114 & & & \\
\hline \multirow[t]{7}{*}{3.564 .382} & 2020 & Bozbağ Caddesi Parkı & 6.072 & & & \\
\hline & & Hasret Sitesi Parkı & 854 & & & \\
\hline & 2010 & Mustafa Dağ Parkı & 593 & & & \\
\hline & 2003 & Teyyaredüzü Parkı & 1.864 & & & \\
\hline & 2003 & Fiskobirlik 75. Yıl Parkı & 985 & & & \\
\hline & & Öğretmenler Sitesi Çocuk Parkı & 1.257 & & & \\
\hline & 2014 & Gençlik Merkezi ${ }^{8}$ & 3.600 & 13.157 & 3.053 & 4.3 \\
\hline Osmaniye/99.988 & & 23 Nisan Çocuk Parkı & 462 & 462 & 866 & 0.5 \\
\hline Erikliman /770.262 & & & & & 416 & \\
\hline Kayadibi /5.142.218 & & & & & 121 & \\
\hline
\end{tabular}

${ }^{4}$ Alanın toplam yüzölçümü 17.820 m2,burada oyun elemanlarının bulunduğu alan dikkate alınmaktadır.

${ }_{5}^{5}$ Çocuk parkı olarak yer verilmekte fakat yenilenmek üzere olduğundan dolayı oyun elemanlarııı kaldıııldı̆ı anlaşılmakta.

${ }^{6}$ Alanın tamamı $26630 \mathrm{m2}$, burada oyun elemanlarııı bulunduğu yaklasıık 2400 m2'lik alan dikkate alınmaktadır.

${ }^{7}$ Alanın tamamı 28037 m2, burada oyun elemanlarının bulunduğu yaklaşık 1000 m2'lik alan dikkate alınmaktadır.

${ }^{8}$ Alanın tamamı $25.750 \mathrm{m2}$, burada oyun elemanlarının bulunduğu yaklaşık $3600 \mathrm{m2}$ 'lik alan dikkate alınmaktadır. 
Kentsel Alanda Çocuk ve Çocuk Oyun Alanları: Giresun Merkez İlçe Örneğinde Bir Araştırma

Küçükköy /1.960.818

Çaykara /4.484.252 162

Aydınlar $/ 1.756 .103$

202

Cumhuriyet /1.301.923

17

Sultan Selim /238.784

Şeyhkeramattin /43.015

Hacı Miktat /131.836

Kapu /44.369

Samanlıkkıranı/996.096

Toplam

${ }^{9}$ Bu veri 7-14 yaş grubuna ait olup, 0-6 yaş grubuna ait veri bulunmamaktadır.

${ }^{10}$ Belirtilen yaş grubuna ait veri bulunmamaktadır. 
Yukarıda yer verilen Tablo 3'de çocuklar için dizayn edilen, oyun elemanlarının bulunduğu parklara yer verilmektedir. Farklı yaş gruplarına hitap eden parklarda ise, çocuklar için ayrılan alanlar dikkate alınmıştır. Bu kapsamda kullanımda olan 50 adet oyun alanının varlığı tespit edilmiştir ${ }^{11}$. Ele alınan yerleşim alanında, 0-14 yaş aralığında çocukların en fazla bulunduğu mahallelerin sırasıyla, Teyyaredüzü, Gedikkaya, Çıtlakkale ve Aksu Mahallelerinin olduğu görülmektedir. Bu mahalleler aynı zamanda sahip oldukları coğrafi özellikleriyle kentleşmenin genişleme gösterdiği yeni yerleşimlere karşlık gelmektedir. Mahallelerin genel nüfusu içinde çocukların oransal durumu incelendiğinde ise, \% 23'lük dilimle en fazla Aksu ve Gedikkaya Mahallelerinde, en az ise \%10'luk dilimle Gaziler ve Güre Mahallelerinde bulunduğu tespit edilmektedir. Tablo 3 incelendiğinde, miktar açısından en fazla oyun alanının 13.157 ile Teyyaredüzü Mahallesi'nde olduğu ve çocuk başına $4.3 \mathrm{~m}^{2}$ lik alanın düştü̆̆̈̈, fakat mahallenin yerleşim ölçeğinin küçük olmasıyla ilişkili olarak en fazla çocuk oyun alanının 9,3 $\mathrm{m}^{2}$ ile Güre Mahallesi'nde olduğu görülmektedir. Ayrıca Teyyaredüzü Mahallesi'nde bulunan 9 çocuk parkının, mahallenin yüz ölçümü dikkate alındığında, dengeli bir dağılım gösterdiği de ifade edilebilir. Dağılım açısından benzer bir durum Çıtlakkale Mahallesi için de söylenebilir. Fakat Güre Mahallesi'ni hariç tutarsak, sahip olunan yüz ölçüm dikkate alındığında çocuk başına $2.5 \mathrm{~m}^{2}$ alan düşen Aksu Mahallesi için aynı şeyi söylemek mümkün gözükmemektedir. Burada belirtmek gerekir ki, çalışmamızın konusu olmamakla birlikte, mahallelerin yüz ölçümü üzerindeki orantısızlık bir ölçek sorununu da gündeme getirmektedir.

Çocuk başına 1,5 $\mathrm{m}^{2}$ asgari kriter dikkate alındığında, çocuk nüfusunun önemli diliminin yaşadığı mahallerde 9.3 ile $1.5 \mathrm{~m}^{2}$ aralığında değişkenlik gösteren oyun alanının olduğu, kırsal nitelikleri ağır basan mahallelerde ise oyun alanlarının bulunmadığı veya yetersiz olduğu görülmektedir. İfade edilenler bağlamında 12 mahallede çocuk oyun alanı bulunmamakta, bu alanlardan $4^{\prime}$ ü kentin merkezi yerleşiminde, 1'i yeni kentleşmekte olan bir noktada ve 7'si ise kırsal niteliği ağırlıklı olan bir alanda konumlanmaktadır.

\footnotetext{
${ }^{11}$ Belirtmek gerekir ki, burada genel kamunun hizmetine sunulmuş oyun alanları dikkate alınmakta, sitelerin kendi içinde oluşturdukları oyun alanları dikkate alınmamaktadır. Ancak bir oyun alanı, bir sitede yer almakla birlikte dışarıdan çocukların kullanımına açıksa, o zaman dikkate alınmıştır.
} 
Parklarda Yer Alan Oyun Elemanlarnın Türleri ve Yaş gruplarna Göre Dağılımı

\begin{tabular}{|c|c|c|c|c|c|}
\hline \multicolumn{2}{|c|}{ Parkta Yer Alan Oyun Elemanları } & \multirow{2}{*}{$\begin{array}{l}\text { Sayısı } \\
97 \\
\end{array}$} & \multirow{2}{*}{$\begin{array}{l}0-3 \\
26 \\
\end{array}$} & \multirow{2}{*}{$\begin{array}{l}4-6 \\
60 \\
\end{array}$} & \multirow{2}{*}{$\begin{array}{l}7-15 \\
11 \\
\end{array}$} \\
\hline Kaydırak & Dalgalı/düz-Tekli/çiftli & & & & \\
\hline & Spiral-Tekli/çiftli & 42 & - & 31 & 11 \\
\hline & Tünel & 7 & - & 5 & 2 \\
\hline Toplam & & 146 & 26 & 96 & 24 \\
\hline \multirow[t]{4}{*}{ Salıncak } & Tek dönerli & - & - & - & - \\
\hline & Çok dönerli & 2 & - & 2 & - \\
\hline & Tek noktalı & 127 & 6712 & 49 & 11 \\
\hline & Bağlantılı & - & - & - & - \\
\hline Toplam & & 129 & 67 & 51 & 11 \\
\hline \multirow[t]{4}{*}{ Atlı Karınca } & Döner koltuklu & 1 & - & 1 & - \\
\hline & Klasik & - & - & - & - \\
\hline & Asslı & 1 & - & 1 & - \\
\hline & Tekli & 4 & - & 4 & - \\
\hline Toplam & & 6 & - & 6 & - \\
\hline \multirow[t]{4}{*}{ Tirmanma } & Merdivenli & 6 & - & - & 6 \\
\hline & İpli & 21 & - & 1 & 20 \\
\hline & Ağaç tipli & 16 & - & - & 16 \\
\hline & Kaya tipli & 20 & - & 3 & 17 \\
\hline Toplam & & 63 & - & 4 & 59 \\
\hline \multirow[t]{3}{*}{ Tahteravalli } & Düşey hareketli & - & - & - & - \\
\hline & Tek noktaya bağlı & 35 & - & 26 & 9 \\
\hline & Çok noktaya bağlı & - & - & - & - \\
\hline Toplam & & 35 & - & 26 & 9 \\
\hline \multirow[t]{2}{*}{ Yaylı Oyun Elemanı } & Trambolin & - & - & - & - \\
\hline & Sabit noktada yaylanma & 10 & - & 10 & - \\
\hline Toplam & & 10 & - & 10 & - \\
\hline Havada Asılı & & 6 & - & - & 6 \\
\hline \multicolumn{6}{|l|}{ Kalmayı Sağlayanlar } \\
\hline Toplam & & 6 & - & - & 6 \\
\hline
\end{tabular}

Parklarda bulunan oyun elemanları incelendiğinde genellikle kaydırak, salıncak, tırmanma araçları ve daha az miktarda tahteravallinin yaygın şekilde yer aldığı görülmektedir. Kaydıraklar, düz, dalgalı ve spiral türleriyle bulunmakta; salıncaklar, tek noktaya bağlı tek yön özellikleriyle karşılık bulmakta; tırmanma araçları ise diğerlerine göre daha fazla çeşitlilik göstererek merdivenli, ipli, ağaç ve kaya tipi türleriyle karşılık bulmaktadır. Bu oyun elemanlarının dışında daha az bulunan tahteravalliler tek noktaya

\footnotetext{
12 Salıncakların bu kategoride yer almasında Acar (2017: 12)'ın da vurguladığı üzere kemerin varlığı dikkate alınmıştır.
} 
bağlı şekilde; yaylı oyuncaklar sabit noktaya bağlı yaylanma şeklinde; havada kalmayı sağlayan araçlar demirde tutunarak ilerleme şeklinde; atlı karıncalar ise daha çok teklişekilleriyle öne çıkmaktadır. Burada belirtmek gerekir ki kaydırak, salıncak ve tahteravalli dışındaki oyun elemanları, bir mahalle parkı olma özelliğinin dışında tüm kentteki çocuklara hitap eden 15 Temmuz Spor Kompleksi, Botanik Bahçe ve Gençlik Merkezi'nin alanında bulunan çocuk oyun alanlarında görülmektedir (bkz. Şekil 1). Denizin doldurulmasıyla ortaya çıkan bu alanlar oyun alanlarının miktarını artırdığı gibi oyun elemanlarını da çeşitlendirmişlerdir.

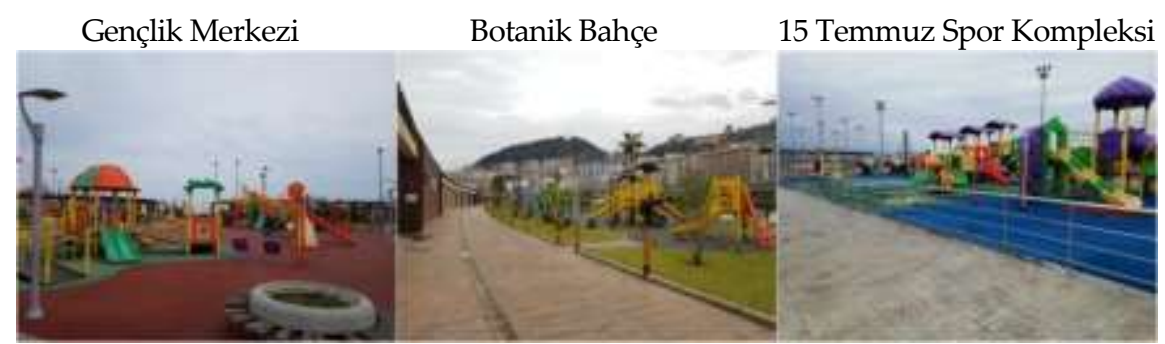

Şekil 1. Mekânsal Genişliği ve Oyun Elemanlan Çeşitliliğiyle Öne Çıkan Parklar

Yaş grupları açısından oyun elemanları incelendiğinde, özellikle 0-3 yaş grubu çocuklarının göz ardı edildiği görülmektedir. Daha çok bu yaş grubuna karşılık gelecek, bir birleri arasında etkileşimi sağlayacak kum havuzu, oyun evleri, tutunmayı ve yer değiştirmeyi sağlayan araçlar gibi oyun elemanlarının varlığı tespit edilememektedir. Mevcut durumda bu yaş grubunun belirli bir evresinde bulunan çocukların kullanabileceği salıncaklar ve kaydıraklar bulunmaktadır. Belirtmek gerekir ki, 0-3 yaş grubu açısından istisnai bir örnek Gençlik Merkezi'nde yer alan oyun alanında bulunmaktadır. Şekil 2'de görülebileceği gibi ilgili yaş grubunun bir araya gelip oynayabileceği bir alan oluşturulmuştur.

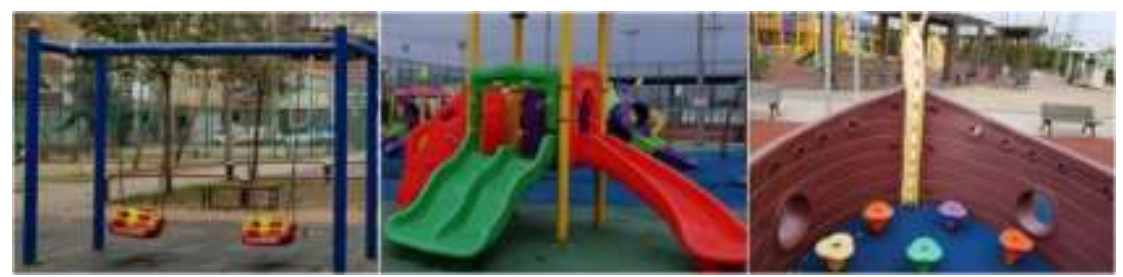

Şekil 2. 0-3 Yaş Çocuklara Yönelik Oyun Elemanları 
Diğer taraftan araştırmanın gerçekleştirildiği parkların yaklaşık yarısında, farklı büyüklüklerde, genellikle zemini taş, etrafı tel örgüyle çevrili olan basketbol veya tenis alanlarının bulunduğu tespit edilmektedir. Bu hususta yine dolgu alanlarına inşa edilen parklar öne çıkmaktadır. Bu imkânlar özellikle 7-15 yaş gurubu için önemli görülmektedir.

\section{Çeşitli Açılardan Oyun Elemanlarının ve Oyun Alanlarının Niteliksel}

\section{Durumu}

Burada oyun elemanları ve oyun alanlarının fonksiyonelliği, güvenliği ve bakımı açısından niteliksel durum incelenmektedir (bkz. Tablo 5).

Tablo 5. Oyun Elemanlarının Fonksiyonelliği, Güvenliği ve Bakımı

\begin{tabular}{|c|c|c|c|c|c|c|c|c|c|c|c|c|}
\hline \multirow{2}{*}{$\begin{array}{l}\text { Parkta Yer Alan Oyun } \\
\text { Elemanları }\end{array}$} & \multicolumn{4}{|c|}{ Fonksiyonelliği } & \multicolumn{4}{|c|}{ Güvenliği } & \multicolumn{4}{|c|}{ Bakımı } \\
\hline & $\mathrm{A}$ & $\mathrm{O}$ & Ç & $\mathrm{H}$ & $\mathbf{A}$ & $\mathrm{O}$ & Ç & $\mathbf{H}$ & $\mathrm{A}$ & $\mathrm{O}$ & Ç & $\mathrm{H}^{13}$ \\
\hline Kaydırak & 7 & 20 & 3 & 3 & 7 & 24 & 2 & 3 & 12 & 15 & 4 & 5 \\
\hline Salıncak & 8 & 19 & 7 & 1 & 4 & 27 & 3 & 2 & 13 & 13 & 4 & 5 \\
\hline Tirmanma & - & 6 & 2 & - & 1 & 6 & - & 1 & 2 & 5 & - & 1 \\
\hline Tahtarevalli & 7 & 18 & 2 & 1 & 2 & 21 & 1 & 3 & 7 & 13 & 2 & 6 \\
\hline Atlı karınca & - & 1 & - & - & - & 1 & - & - & - & 1 & - & - \\
\hline Yaylı oyuncaklar & 1 & - & 1 & - & - & 2 & - & - & - & 2 & - & - \\
\hline $\begin{array}{l}\text { Asılı kalmayı sağlayan } \\
\text { araçlar }\end{array}$ & - & 3 & - & - & - & 3 & - & - & - & 3 & - & - \\
\hline
\end{tabular}

Oyun elemanlarının fonksiyonelliği açısından parklar incelendiğinde "orta" düzeyde bir durumun varlığı öne çıkmaktadır. Fonksiyonellik açısindan en önemli unsur salıncak ve kaydırakların diğer oyun elemanlarının konumu arasında ortaya çıkmaktadır. Oyun elemanları arasında mesafenin azlığ1 veya iç içe geçmişliği, özellikle küçük yaş grubundaki çocuklar için kullanımı düşürmekte ve bazı riskler ortaya çıkarabilmektedir. Yapılan incelemede fonksiyonelliği düşüren diğer önemli bir husus ise, daha çok 2-4 yaş aralığına hitap eden kaydıraklar ile daha üst yaş grubuna hitap eden kayd1rakların aynı ünite içinde yer almasıdır. Farklı yaş gruplarının aynı merdiveni kullanıyor olması fonksiyonelliği azaltmaktadır (bkz. Şekil 3).

${ }^{13} A: A z$, O: Orta, Ç: Çok, H: Hiç. 


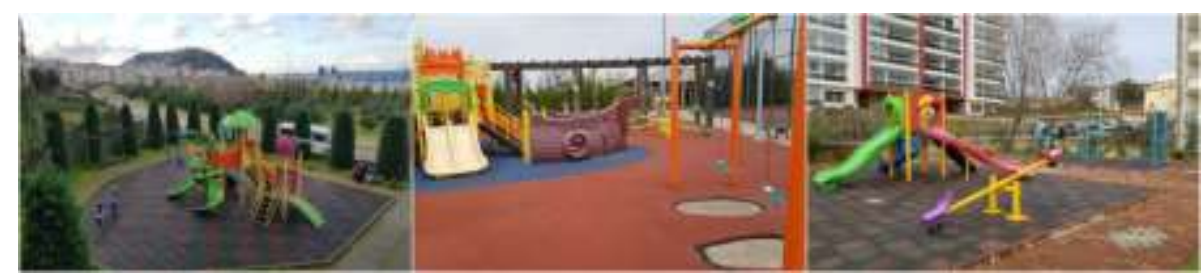

Şekil 3. Oyun Elemanlarının Fonksiyonelliği

Oyun elemanlarının bakım durumu büyük oranda "az" ve "orta" olarak tespit edilmektedir. Bu noktada bakımla ilişkili yaygın olarak salıncak kemerlerinin kırıklığı, bağlantı noktalarının aşınmışlığı oyun elemanlarının kırık olması öne çıkmaktadır (bkz. Şekil 4). Genel olarak ele alındığında oyun elemanlarının nispeten yeni olması, bakım açısından çok olumsuz bir durumu yansıtmamaktadır. Ancak tüm oyun elemanları ve parkın geneli açısından bakımsız olan dört park bulunmaktadır. Bu parklar Hacı Siyam Mahallesinde bulunan 19 Eylül Çocuk Parkı, Aksu Mahallesi'nde Deniz Sitesi çocuk parkı, Çıtlakkale Mahallesi'nde Sönmez Caddesi çocuk parkı ve Teyyaredüzü Mahallesi Mollaoğlu Sokakta bulunan çocuk parkı.

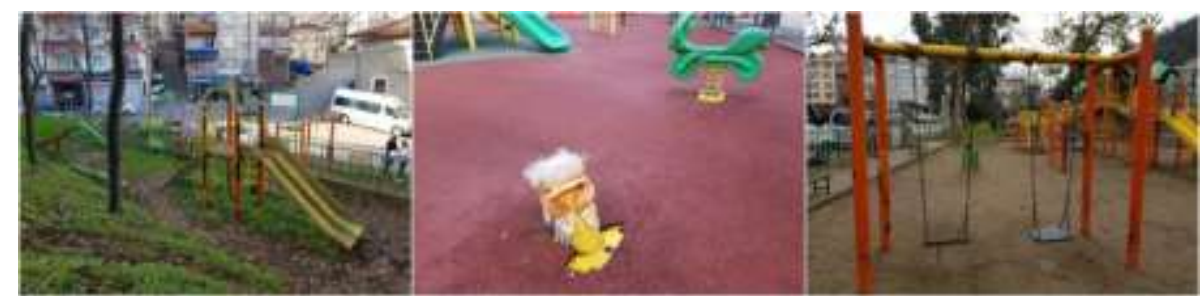

Şekil 4. Oyun Elemanlarının Bakımı

Oyun elemanlarının ve oyun alanının geneli dikkate alındığında, büyük oranda "orta" düzeyde güvenli olduğu tespit edilmektedir. Oyun elemanlarının sağlamlığı, bariyerlerin varlığı, zemin kaplama, oyun elamanlarının bulunduğu konum ve genel olarak park alanının koruma (kuşatma) çemberi içine alınması güvenliği sağlayan unsurlardır. Fakat bakımların zamanında yapılmaması, uygun olamayan oyun elemanlarının kullanılması (örneğin kaydırağın yere inme noktasındaki yükseltinin uygunsuzluğu, bkz. 
Şekil 5), "yakalama alanlarının" varlığ $1^{14}$, araç yoluyla bağlantı noktalarında bariyerlerin bulunmaması, rögar gibi unsurların varlığı, trafo, gaz dağıtım ünitesi gibi araçların bulunması, oyun alanlarının güvenliğini düşürmektedir (bkz. Şekil 5). Bu bağlamda incelenen 37 parkın 6 tanesinde trafo veya gaz dağıtım merkezinin varlığı tespit edilmektedir.

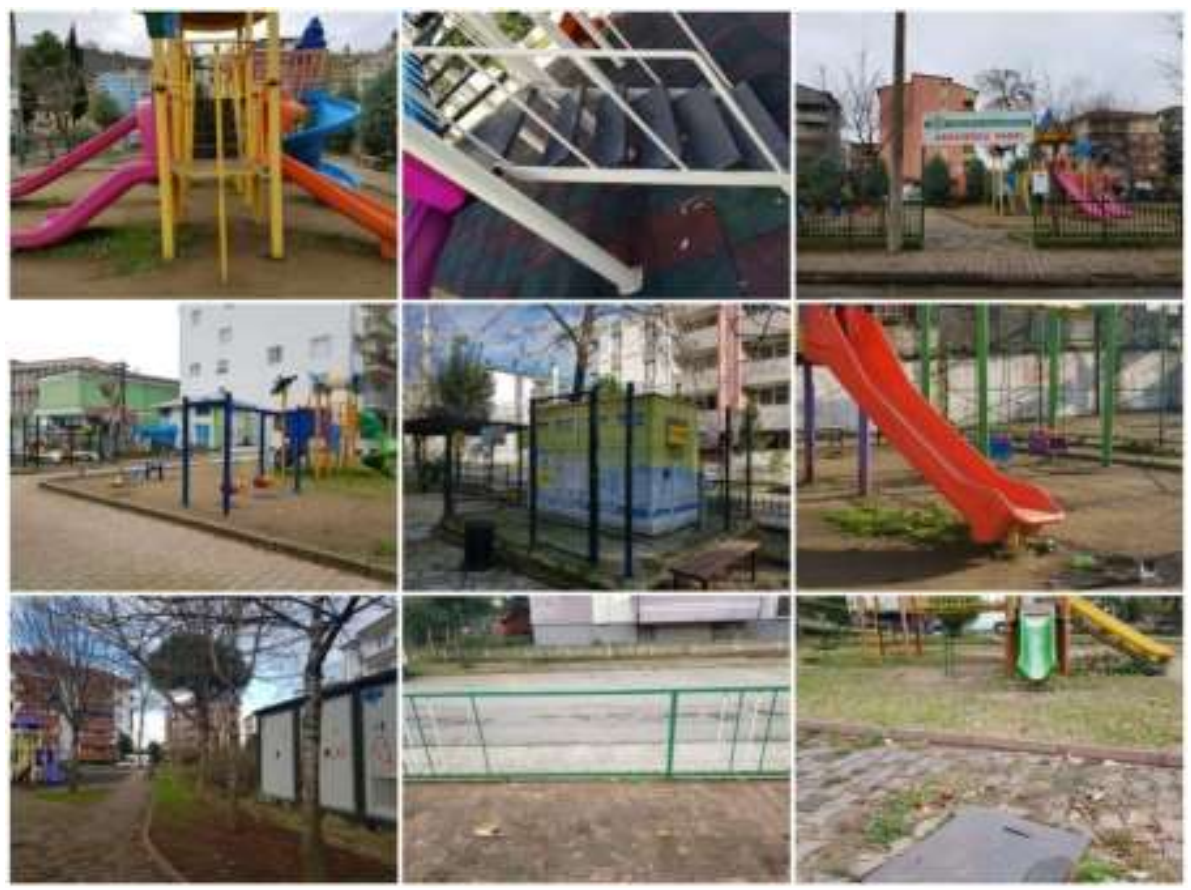

Şekil 5. Oyun Alanının ve Elemanlarının Güvenliği

Oyun Elemanlarında ve Oyun Alanınn Zemininde Kullanilan Malzemelerin Durumu

Oyun elemanlarında kullanılan malzeme açısından incelendiğinde plastik malzemenin baskın şekilde öne çıktığı görülmektedir. Plastik malzemeyi tamamlayan malzeme ise demirdir. İp ise tırmanma elemanlarının yap1minda kullanılan bir malzeme olarak tespit edilmektedir. Diğer taraftan

\footnotetext{
${ }^{14}$ Korkulukların kullanan yaş grubuna uygun olmaması, el veya ayağın boşluğa gitme durumu. Akkülah ve Güngör, 2009: 13.
} 
ahşap malzeme, çok sınırl düzeyde bazı geçiş noktalarında kullanılmakla birlikte, tercih edilmeyen bir malzeme olduğu anlaşılmaktadır (bkz. Tablo $6)$.

Tablo 6. Oyun elemanlarn ve zemin malzemeleri

\begin{tabular}{|c|c|c|c|c|c|c|c|c|c|}
\hline \multirow[b]{2}{*}{$\begin{array}{l}\text { Parkta Yer Alan Oyun } \\
\text { Elemanları }\end{array}$} & \multicolumn{4}{|c|}{ Oyun elemanı malzemeleri } & \multicolumn{5}{|c|}{ Zemin malzemeleri } \\
\hline & $P+D$ & $\mathbf{D}$ & $\mathbf{A}$ & $\overline{\mathbf{I}}$ & Ç & B & $\mathbf{K}$ & $\mathbf{K}$ & $\mathbf{T}^{15}$ \\
\hline Kaydırak & 130 & & & & & 2 & 27 & 5 & 2 \\
\hline Salıncak & 115 & & & & & 2 & 27 & 4 & 2 \\
\hline Tirmanma & 45 & 1 & & 15 & & 1 & 7 & & 1 \\
\hline Tahtarevalli & 35 & & & & & & 23 & 2 & 2 \\
\hline Atlı karinca & 6 & & & & & & 1 & & \\
\hline Yaylı oyuncaklar & & 10 & & & & & 2 & & \\
\hline $\begin{array}{l}\text { Havada asılı kalmayı } \\
\text { sağlayan araçlar }\end{array}$ & & 6 & & & & & 4 & & \\
\hline
\end{tabular}

Oyun alanlarının zemin malzemesi incelendiğinde yaralanmaları azaltacak bir malzeme olan kauçukun yaygın şekilde kullanıldığı görülmektedir. Az sayıda oyun alanında ise toprak ve kum zeminin olduğu tespit edilmektedir (bkz. Şekil 6).

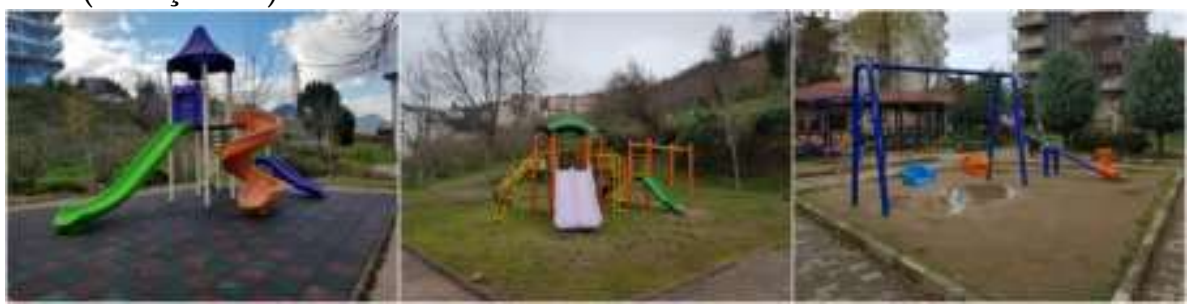

Şekil 6. Oyun Alanlarmin Zemin Durumu

\section{Oyun Alanlarının Tamamlayıcı Unsurları}

Oyun alanı tamamlayan, güvenliğini, işlevselliğini ve kullanımını etkileyen bazı unsurların varlığı önemli görülmektedir (bkz. Tablo 7).

${ }^{15}$ P+D: Plastik ve demir, D: Demir, A: Ahşap, i: ip, Ç: Çakıl, B: Beton, K: Kauçuk, K: Kum, T: Toprak. 
Tablo 7. Oyun Alanı Tamamlayıcılarnın Durumu

\begin{tabular}{|c|c|c|c|c|c|}
\hline \multicolumn{2}{|c|}{ Oyun Alanı Tamamlayıcıları } & \multicolumn{2}{|c|}{ Var } & \multicolumn{2}{|c|}{ Yok } \\
\hline & & $\mathbf{F}$ & $\%$ & $F$ & $\%$ \\
\hline \multicolumn{2}{|c|}{ Çeşme } & 8 & 22 & 29 & 78 \\
\hline \multirow{4}{*}{ 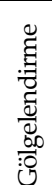 } & Tente & - & & 37 & 100 \\
\hline & Pergole & 9 & 24 & 28 & 76 \\
\hline & Geniş yapraklı ağaç & 14 & 38 & 23 & 62 \\
\hline & Dar yapraklı ağaç & 8 & 22 & 29 & 78 \\
\hline \multicolumn{2}{|c|}{ Tuvalet } & 3 & 8 & 34 & 92 \\
\hline \multicolumn{2}{|c|}{ Oturma bankı } & 31 & 84 & 6 & 16 \\
\hline \multicolumn{2}{|c|}{ Kamelya } & 9 & 24 & 28 & 76 \\
\hline \multicolumn{2}{|c|}{ Çocuk bakım mekânı } & 2 & 5 & 35 & 95 \\
\hline \multicolumn{2}{|c|}{ Bisiklet yolu } & 2 & 5 & 35 & 95 \\
\hline \multicolumn{2}{|c|}{ Serbest alan } & 9 & 24 & 28 & 76 \\
\hline \multicolumn{2}{|c|}{ Yürüyüş yolu } & 3 & 8 & 34 & 92 \\
\hline \multicolumn{2}{|c|}{ Spor aletleri } & 9 & 24 & 28 & 76 \\
\hline \multicolumn{2}{|c|}{ Aydınlatma } & 18 & 49 & 19 & 51 \\
\hline \multicolumn{2}{|c|}{ Çöp kutusu } & 27 & 73 & 10 & 27 \\
\hline \multirow{4}{*}{ 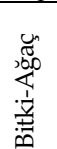 } & Ağaç & 25 & 68 & 12 & 32 \\
\hline & Çalı & 17 & 46 & 20 & 54 \\
\hline & Çiçek & 10 & 27 & 27 & 73 \\
\hline & Yer örtücü bitki & 14 & 38 & 23 & 62 \\
\hline
\end{tabular}

Gerçekleştirilen incelemede oyun alanlarının sadece sekizinde kullanılabilir durumda çeşmenin varlığı tespit edilmektedir (bkz. Şekil 7).

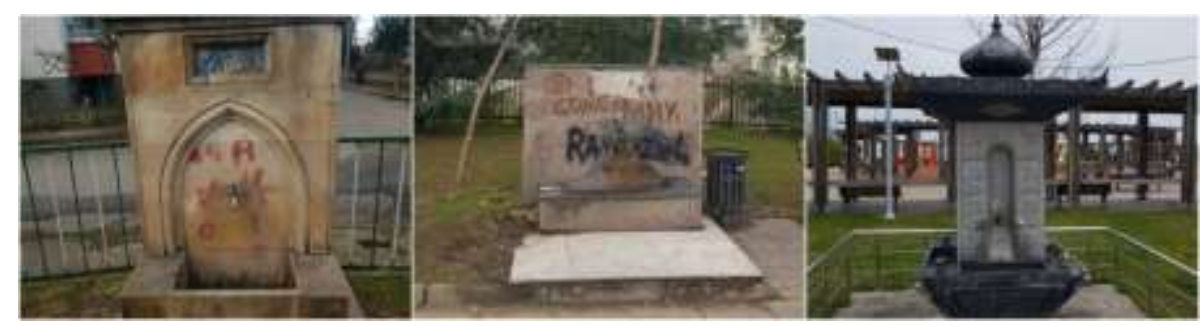

Şekil 7. Oyun Alanlarında Çeşme

Çocuklara eşlik eden aileleri açısında oyun alanlarının tamamlayıcı bir unsuru oturma alanlarıdır. Özellikle oyun elemanlarının bulunduğu noktaya yakın bir yerde bulunması önemli görülmektedir. Bu bağlamda yapılan incelemede oturma banklarının altısı hariç diğer oyun alanlarında, oyun elemanlarına yakın bir noktada konumlandırılarak yer verildiği görülmek- 
tedir. Oturma elemanlarının başka bir türü olan kamelyaların ise dokuz parkta bulunduğu tespit edilmektedir (bkz. Şekil 8).

Oyun alanlarında güneşin zararlı etkilerine karşı gölgelendirme işlevi gören araçlar açısından bakıldığında ağaçların ve pergolenin öne çıktığı görülmektedir (bkz. Şekil 9).

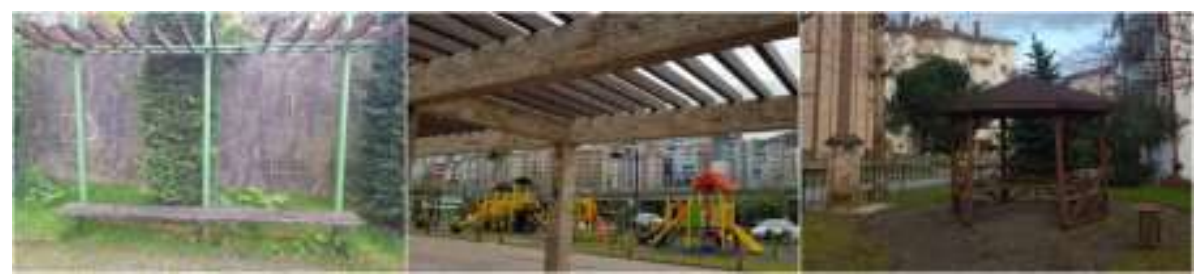

Şekil 8. Oyun Alanlarnda Oturma Elemanlarn ve Pergole

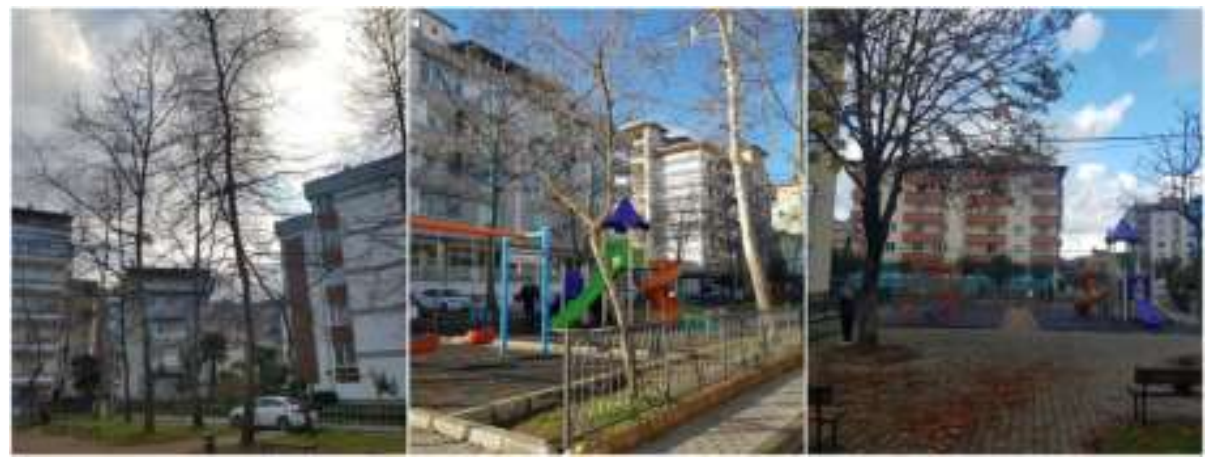

Şekil 9. Oyun Alanlarında Gölgelendirme Aracı Olarak Ağaçlar

Oyun alanlarının önemli bir tamamlayıcısı da tuvalettir. Yapılan incelemede sadece üç oyun alanında (Botanik Bahçe, 15 Temmuz Spor Kompleksi ve Gençlik Merkezi) kamunun kullanımına açk tuvaletin varlığı tespit edilmektedir. Diğer taraftan küçük yaş grubunda çocukların beslenme ve temizliği için ihtiyaç duyulan bakım alanlarının da ancak iki oyun alanında bulunduğu anlaşılmaktadır. 


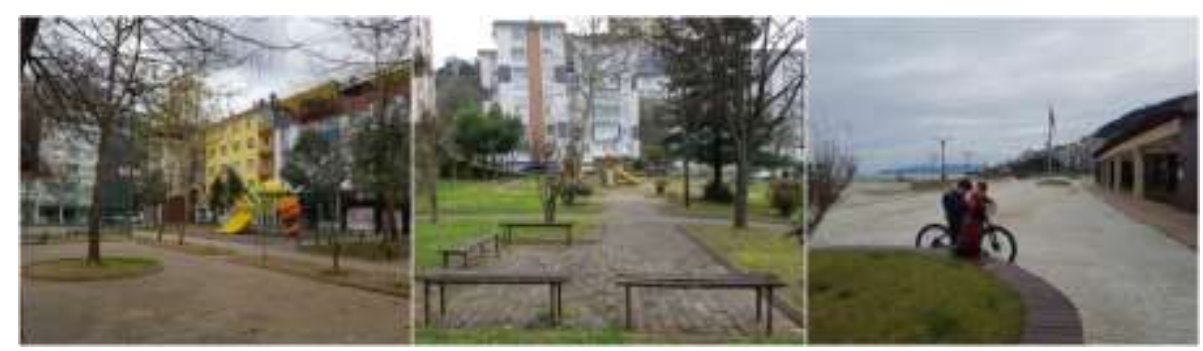

Şekil 10. Oyun Alanlarnda Serbest Alan

Oyun elemanlarının dışında çocukların kendi aralarında oynayabileceği, koşabileceği alanlar, incelenen oyun parklarının sekizinde bulunmaktadır. Özellikle Botanik Bahçe'de bırakılan boş alan, çocuklara yönelik çeşitli açılardan (bisiklet kullanmak, uçurtma uçurmak, koşmak gibi) önemli bir imkân sunmaktadır (bkz. Şekil 10).

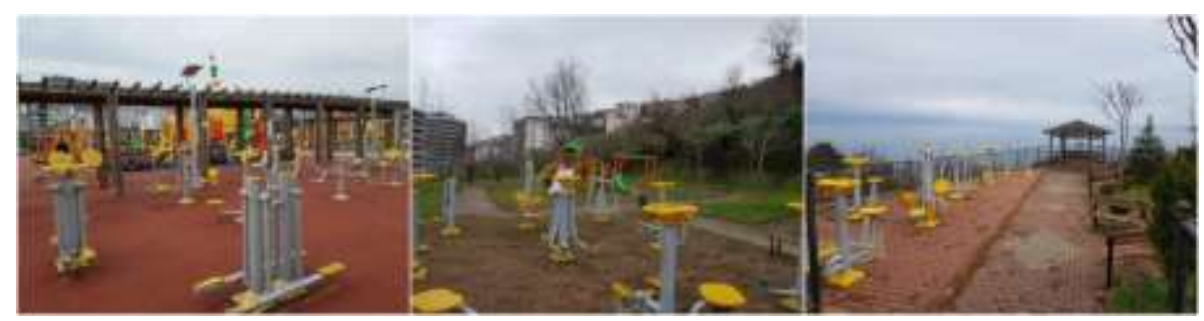

Şekil 11. Oyun Alanlarnda Spor Aletleri

Oyun alanlarının dokuzunda spor aletleri bulunmaktadır (bkz. Şekil 11).

Aydınlatma açısından incelendiğinde, oyun alanlarının 18'inde aydınlatmanın olduğu tespit edilmektedir. Fakat dolgu alanlarına konumlandırılan oyun alanlarına özel ışıklandırmaların yapıldı̆̆ı, diğer oyun alanlarında ise genel sokak aydınlatması bağlamında aydınlatma düzeneğinin kurulduğu tespit edilmektedir.

Yürüyüş yapma ve bisiklet kullanıma yönelik ayrıca bir yol düzenlemesinin yine dolgu alanlarına konumlandırılan oyun alanlarında ayrıca bir düzenlemeye gitmeden yer bırakıldığı anlaşılmaktadır.

Diğer taraftan çöp kutularının büyük oranda oyun alanlarında bulunduğu, ancak sekiz parkta bulunmadığı tespit edilmektedir. 


\section{Diğer Bulgular}

Konumu ve sahip olduğu oyun elemanlariyla kentin geneline hizmet eden iki parkta (Gençlik Merkezi ve Botanik Bahçe) güvenlik görevlisi bulunmaktadir.

İki park (bkz. Şekil 12) hariç parkların bulunduğu konum, etrafı açık, gün boyu güneş alabilecek bir durumdadır.

Dolgu alanlarında yer alan üç park hariç, konutların bulunduğu konuma göre oyun alanları yürüme mesafesinde bulunmaktadır.

Ele alınan parkların büyük çoğunluğunun tekerlekli bebek ve engelli arabalarının girişine ve dolaşımına uygun değildir. Park girişi rampaları bulunmamaktadır veya olması gerektiği şekilde yapılmamıştır.

Gençlik Merkezi'nde bir oyun elamanında dikkate alınmakla birlikte, engellilere uygun oyun eleman bulunmamaktadır.

Geleneksel oyunların oynanabileceği alanlar bulunmamaktadır.

Diğer taraftan oyun alanlarının, muhtarlık ofisleri ve trafo/gaz dağıtım istasyonlarının yapımıyla daraltıldığı tespit edilmektedir.

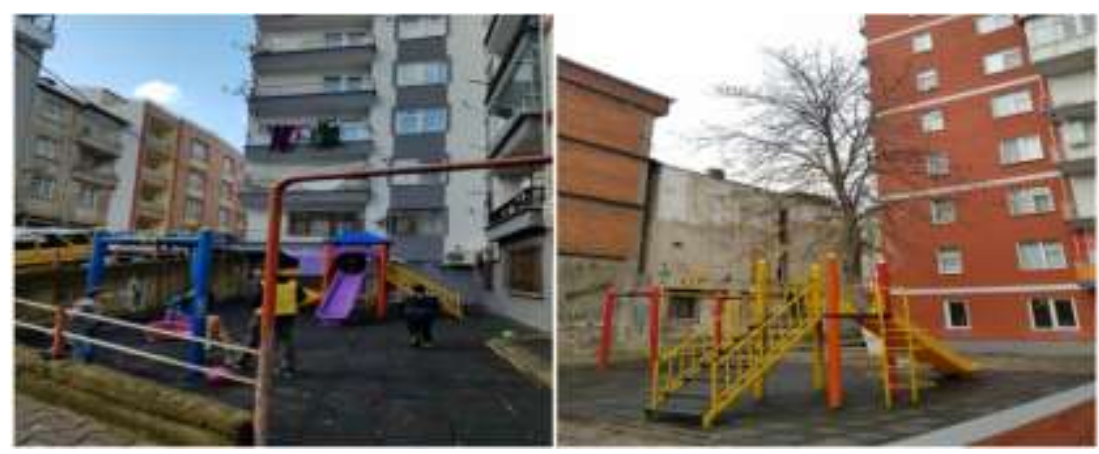

Şekil 12. Oyun Alanlarnın Bulunduğu Konum

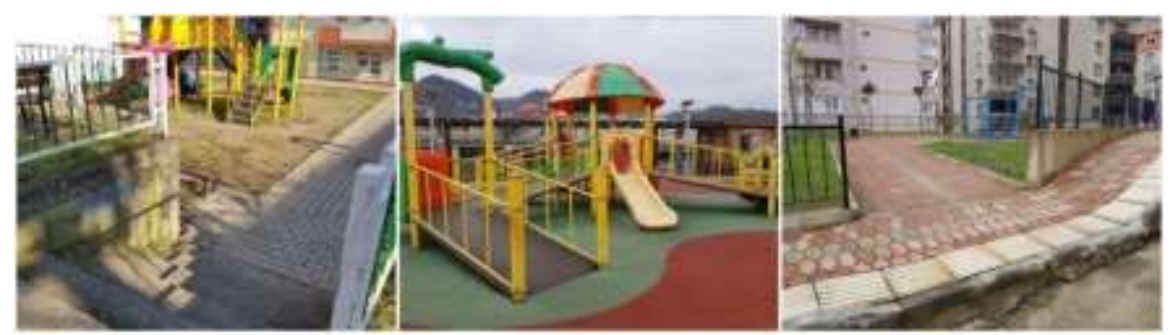

Şekil 13. Oyun Alanlarının Engellilere Yönelik Uyumu 


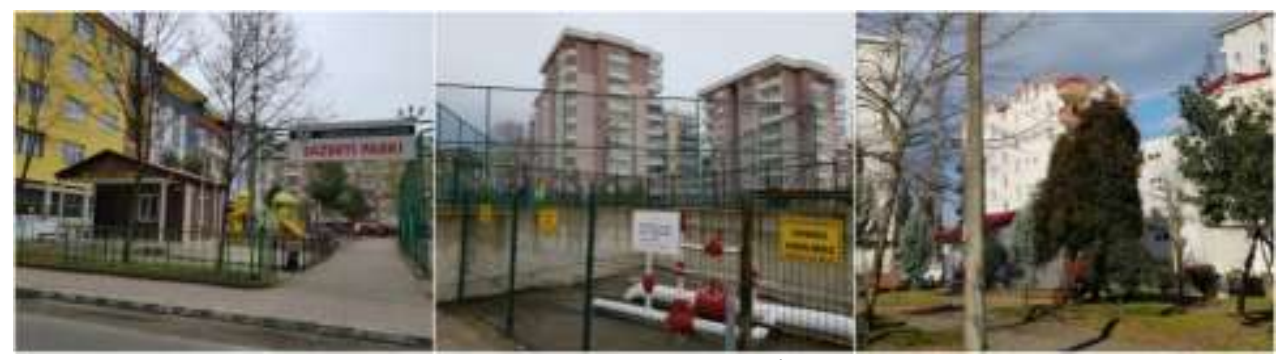

Şekil 14. Oyun Alanlarının İsgali

\section{Tartışma ve Genel Değerlendirme}

Giresun merkez ilçede 50 adet aktif çocuk oyun alanının /parkının olduğu tespit edilmektedir. Parkların tamamının kuruluş yılına ait bilgi bulunmamakta, 23 tanesinin bilgisi elde edilmektedir. Bu bilgisi olan parkların da 14 tanesinin 2014 sonrası kurulduğu görülmektedir. Adı geçen yıl aynı zamanda Giresun Belediyesi'nin Çocuk Dostu Şehir projesine dahil olduğu zamanı göstermektedir. Bu proje kapsamında gerçekleştirilen eylem planı çalışmalarında çocuklar tarafından talep edilen hususlardan biri de engelsiz çocuk parkı olduğu ifade edilmektedir (Giresun Belediyesi Çocuk Birimi Koordinatörü, 20. 02. 2020). Yürütülen bu çalışmaların dolaylı olarak parkların niceliğinde de bir artışa destek olduğu değerlendirilmesi yapılmaktadır. Yine adı geçen proje kapsamında oyun elemanlarının çeşitliliği ve niteliğini artırmaya yönelik mahalle odaklı çabaların gösterildiği (23 Nisan ve Sazbeyi Çocuk Parkı) fakat çeşitli sebeplerle sürdürülemediği belirtilmektedir (Giresun Belediyesi Çocuk Birimi Koordinatörü, 20. 02. 2020).

Bir çocuk oyun alanının $250 \mathrm{~m}^{2}$ den az olmaması vurgulanmaktadır (Akt. Özalp vd., 2012). Bu bağlamda incelenen çocuk parklarından dördü (26 Evler üstü, Tozlu Sokak, İnönü Caddesi ve Mollaoğlu Sokak), ilgili alan kriterinin altında kalmaktadır. Dolgu alanlarına yapımı gerçekleştirilen oyun alanlarıyla birlikte, oyun elamanlarının bulunduğu mekan genişlemiş ve çeşitlilik artmıştır. Fakat bu alanlar, mahalle parkı olmanın dışında daha çok araçla ulaşımı sağlanan, ilçenin geneline hitap eden mekânlardır. Oyun alanlarının etkileşim açısından işlevselliği daha çok mahalle düzeyinde yer alan mekanlar üzerinden kurulmaktadır. Bu durum dikkate alındığında, oyun alanlarının mahallede bulunması önemlidir. Hatta oyun alanlarının mahalle düzeyinde varlığının önemli olduğu belirtilmenin yanında, çocuk- 
ların bulunduğu konutlar dikkate alınarak belirli mesafe ve süre hesaplaması yapılmaktadır (Akt. Bahtiyar Karadeniz, 2016: 1199). Bununla birlikte, oyun alanlarının sınırlılığı, oyun elemanı türlerinde de bir eksikliği ortaya çıkarmaktadır.

Gerçekleştirilen incelemede, oyun parklarında yer alan oyun elemanlarının türlerinde, üç oyun parkı (Botanik Bahçe, 15 Temmuz Spor Kompleksi ve Gençlik Merkezi) hariç, çeşitlilik olmadığı tespit edilmektedir. Yaygın şekilde salıncak ve kaydırağın varlığı görülmektedir. Benzer bir tespit Nehşehir (Aklıbaşında, Tirnakçı ve Özhancı, 2018,s.66), Konya (Duman ve Koçak, 2013,s.6), Aydın (Samur ve Kızıltepe, 2018,s.36) ve Çanakkale (Başaran Uysal, 2015,s.430) özelinde gerçekleştirilen araştırmalarda da yapılmaktadır. Oyun, çocuk için fiziksel aktivite olmasının yanı sıra zihinsel gelişimin destekleyicisidir. Bundan dolayı oyun elemanlarının çeşitli türlerinin varlığı, çocuğun yaratıcılığı yönünde olumlu etkisinin olduğu kabul edilmektedir. Ayrıca önemli görülen bir başka husus ise, endüstrileşmenin etkisi altında oyuncakların ve oyun elemanlarının tek tipleşmesidir (bu konuda detaylı bilgi için bkz. Onur, 2010). Bu noktada Çakırer-Özservet (2018b,s.64) şu ifadelerde bulunmaktadır:

Çocuk-oyun ikilisinin başarısı, özgürce oyun oynanabilecek fiziksel mekânların olmasinda yatar. Oyun mekân, esnek kullanıma, yaratıcı fikirlere izin vermelidir, çünkü aşırı kontrol oyunun doğasını mahveder ve kapah oyun alanlarn genellikle bu niteliktedir. Ve çocuklar doğası gereği en çok planlanmamış oyunları severler. Bugün kentsel mekânlar planlanırken, çocuklar adına hazır şablon çocuk oyun alanları (parklar) planlanmakta ve uygulanmaktadır. Çocuklarm ev-okul gibi iç mekânlarda zaten yeterince kısıtlanmış, sinırlandırılmış olduğunu göz önüne alırsak; açık, kamusal (sokaklar, parklar gibi) mekânlarda da bunun devamı niteliğinde oyun oynama aktivitelerini simırlandırmak ve bir şablona sı̆̆dırmak tehlike içermektedir. Çocukların farkh oyun mekânları görmeleri, farklı mekânlarda kendi oyunlarını kurmaları ve bir mekânda birden fazla oyun kurmalarna izin vermeyen şabloncu anlayışla, çocuklarm oyun hakkı gasb edilmektedir.

Şişman ve Özyavuz (2010,s.21) tarafından, oyun parklarının oyun türleri açısından yetersiz olması çocukta zihinsel ve fiziksel ciddi eksiklikler ortaya çıkarabileceği ifade edilmektedir. Coşkun $(2015, \mathrm{~s} .152)$ ise, parkların çoğunluğunda aynı oyun elemanlarının tercih edilmiş olmasını, çocukların istek ve gelişim özelliklerinin dikkate alınmadığının bir göstergesi olarak tespit etmektedir. Yine Coşkun (2015,s.152), çocuk oyun alanlarında yer alan oyun 
elemanlarının, çocuğun zevkle kullanabileceği ve fiziksel, zihinsel, ruhsal ve sosyal yönden gelişmesine yardımcı olacak şekilde yapılmasına dikkat çekmektedir. Bunlar kum havuzları, müzik aletleri, denge elemanı, tırmanma duvarı, doğal elemanlar, oyun evleri, eğitici levhalar gibi çocuğun zevkle oynabilecekleri elemanladır. Çocuk oyun alanlarının yapımında oyun elemanlarının çeşitlendirilmesi önemli görülmektedir.

Diğer taraftan parklarda yapılan incelemede, hem genel düzeyde oyun alanın oluşturulmasında hem de oyun elemanlarının tercihinde engellilerin dikkate alınmadığı tespit edilmektedir. Benzer durum Özalp vd. (2012)'nin Atvin'de, Türkan ve Önder (2011,s.75)'in Balıkesir'de, Kuşuluoğlu (2013,s.120)'un Kadıköy'de gerçekleştirdiği araştırmalarda da tespit edilmektedir. Fakat Çocuk Dostu Kent projesi kapsamında Giresun Belediyesi için hazırlanan eylem planında şöyle bir ifade yer almaktadır: "Giresun Belediyesi engelli çocuklara göre adapte adilmiş bir oyun alanı kurarak oyun ve gelişim haklarna erişmelerinde engelli çocuklara destek olacaktır". Planlama düzeyinde yer verilen bu düzenlemenin hayata geçirilmesi, engelli bireylerin oyun alanlarına katılımını teşvik ederek, sosyal hayata entegrasyonunu artıracaktir.

Yaş grubuna göre oyun alanları incelendiğinde, doğrudan 0-3 yaş grubu çocukların kendine özgü özelliklerinden (bkz. Kuşuluoğlu, 2013,s.29) hareketle oyun ihtiyacına karşılık gelebilecek salıncak ve kaydırakların dişında, kısmen bir adet (gençlik merkezinde) oyun parkı bulunmaktadır. Mahallerdeki parklar baz alındığında, 0-3 yaş grubu çocukların güvenli şekilde oyun oynayabilecekleri oyun alanı ve elemanlarının varlığı söz konusu değildir. Benzer durum diğer yerleşimlerde de görülmektedir (bkz. Aklıbaşında, Tırnakçı ve Özhancı, 2018,s.67). Oyun oynamak, tüm çocuklara tanınmış olan bir haktır. Fakat alan ve eleman eksikliğinden ortaya çıkan bu durum, çocuğun oyun hakkını kısıtlamaktadır. Kuşçuoğlu (2013,s.28), çocukların yaşlarına göre yeteneklerinin ve becerilerinin değişkenlik gösterdiğinin altını çizmektedir. Bulut ve Kılıçaslan $(2009, \mathrm{~s} .81)$ ise, parklarda yer alan oyun elemanlarının yaş gruplarına göre ayrılmasını vurgulamaktadır. $\mathrm{Bu}$ durum aynı zamanda, çocukların düşme, yaralanma gibi durumlarını engelleyecektir. Araştırmada, oyun elemanlarının çeşitlilik sergilemediği görülmektedir. Çocuklar sınırlı sayıda olan oyun elemanlarını kullanmaktadır. Sınırlı oyun elemanlarının olduğu bu parklar, her yaş grubu çocuk içinde üzerinde çalışılması gereken bir konudur. Ortaya çıkan sınırılık zihinsel, 
fiziksel vb. yönden çocukları etkilemektedir. Çocukluk döneminin önemli bir evresi olan 0-3 yaş grubunun gelişimini destekleyecek oyun elemanlarının eksikliğinin giderilmesi önemli bulunmaktadır. Bilhassa suyla bağlantılı oyun elemanları ve kum havuzları, bu yaş grubu için öne çıarılmaktadır (Türkan ve Önder, 2011,s.78).

Oyun parklarında bulunan oyun elemanları fonksiyonellik, güvenlik ve bakım açısından genel olarak değerlendirildiğinde, fonksiyonelliğin orta düzeyde olduğu görülmektedir. Fonksiyonellik, daha çok oyun elemanlarının arasındaki mesafe göz önünde bulundurularak değerlendirilmiştir. Bulgularda da yer verildiği üzere, özellikle salıncak ve kaydırak arası mesafenin az olması, küçük yaşlardaki çocuklar açısından tehlike arz etmektedir. Benzer şekilde farklı yaş gruplarına hitap eden oyun elemanlarının bir ünite içinde yer alması, riskleri barındırmaktadır. Bundan dolayı park elemanları dizayn edilirken her yaş grubunda yer alan çocukların güvenliği göz önünde bulundurulmalıdır. Yapılan araştırmada, büyük yaş grubunun küçük yaş grubu ile aynı kaydırak ünitesini paylaşması, güvenlik eksikliğini ortaya koymaktadır. Salıncağın diğer oyun elemanlarından kesin bir şekilde ayrılmasına Acar (2017: 12) da dikkat çekmektedir. Konya (Akkülah ve Güngör, 2009,s.12) ve Aydın (Ballığlu, 2015,s.91) illerinde gerçekleştirilen araştırmada da benzer bir tespit yapılmaktadır. Kuşcuoğlu (2013,s.40)'nun aktardığına göre, çocuk oyun alanlarında ortaya çıkan kazaların çoğu, çocukların kendi yaş gruplarına ait oyun elemanlarını olmamasından kaynaklanmaktadir.

Oyun elemanlarının bakımı açısından; aşınmaların, kopmaların, paslanmaların, kırılmaların varlığı görülmektedir. Bu durumların, açı havada yer alan oyun elemanlarının genelinde görüldüğü anlaşılmaktadır (bkz. Çoşkun, 2015). Fakat iyi örneklerin de varlığı bilinmektedir (bkz. Duman ve Koçak, 2013,s.7). Parkın içinde yer alan tüm elemanların bakım ve güvenliği bütünsel olarak ele alınmalıdır. Zira çocuğun serbestçe oynayabildiği bu alanlar güvenli olması gerekir. Oyun alanlarının temel güvenliğinin yanı sıra oyun elemanlarının bakımı da dikkat edilmesi gereken hususlardandır. Oyun elemanlarının düzenli bakımının olması çocuğun darbe, düşme ve yaralanma gibi durumlarda olumlu yönde etkili olacaktır.

Gerçekleştirilen araştırmada dikkat çeken bir husus da, incelenen oyun parklarının yaklaşık yarısında, farklı ölçütlerde ve nitelikte basketbol veya 
tenis oyun alanlarının bulunmasıdır. Bu imkân, özellikle 7-15 yaş grubu için önemli bulunmaktadır.

Parkları genel güvenlik açısında ele aldığımızda ise, park alanının etrafının bariyerlerle çevrili olması önem kazanmaktadır. Araştırmada incelenen parkların büyük çoğunluğunda etrafını saran bariyerler bulunmakla birlikte, oyun parkına giriş-çıkış sağlayan noktalarda kapının veya hızlı çıkışını engelleyecek bir bariyerin olmayışı, güvenlik açısından bir tehdit oluşturmaktadır. Konya ilinde gerçekleştirilen araştırmada da benzer duruma dikkat çekilmektedir (Akkülah ve Güngör, 2009,s.11). Özyavuz (2010,s.21) Tekirdağ ili kapsamında yapmış olduğu araştırmada da, oyun alanlarının güvenlik açısından yetersizliklerine dikkat çekilmektedir. Ayrıca güvenlik açısından risk oluşturan başka bir husus da trafo/gaz dağıtım istasyonlarının varlığıdır. Diğer bazı örneklerde de benzer risklerin tespit edildiği anlaşılmaktadır (Akkülah ve Güngör, 2009,s.13). Bunun yanı sıra oyun alanlarının gün boyu güneş alan bir yerde olması, çocuğun gelişimi açısından yararlı olmaktadır. Yapılan araştırmada 2 park dışında, parkların tamamının gün boyu güneş aldığı tespit edilmiştir. Oyun elemanlarının bulunduğu zeminin kauçuk olması ve etrafının taşla çevirili olması parkın fonksiyonelliğini kısıtlamaktadır. Yılmaz ve Bulut $(2002$, s.348) oyun alanında uçurtma uçurtmak, koşmak gibi faaliyetleri yerine getirmek için açık serbest alanlara ve sığınak, depo, WC, çeşme, yürüme alanları, vb. gibi çok amaçlı malzeme ve kullanımların artmasına dikkat çekmektedir. Bu araştırmada incelenen oyun parklarında, park içinde erişimi sağlayacak yolların ve yeşil alanların dışında serbest alanların 8 parkta bulunduğu tespit edilmektedir. Serbest alanlar, tekerlekli oyun araçlarının kullanımı, uçurtma vb. eylemlerin gerçekleştirilmesi gibi faaliyetler açısından önem kazanmaktadır (Aklıbaşında, Tırnakçı ve Özhancı, 2018,s.67). Diğer taraftan oyun alanlarının tamamlayıcllardan biri olan oturma banklarının parkların çoğunluğunda (31 adet) bulunduğu görülmektedir. Banklar, ailelerin oyun esnasında çocukları izleme kolaylığı sağlaması açısından önemli bulunmaktadır (Kuşuluoğlu, 2013,s.121). Ayrıca diğer tamamlayıcı unsurlardan tuvaletin 3, çeşmenin 8, spor aletlerinin 9, çocuk bakım mekanının 2, yürüyüş yolunun ise 3 çocuk parkında bulunduğu tespit edilmektedir. Konya ili özelinde yapılan araştırmada da çeşme ve tuvaletin oyun alanlarında yokluğu tespit edilmektedir (Duman ve Koçak, 2013,s.8). 
Diğer açı ve yeşil alanlarda olduğu gibi kentsel alanda bulunan çocuk oyun alanlarının yetki ve sorumluluğu belediyeye verilmiştir. Kuşçuoğlu (2013,s.122) da kamusal oyun alanlarında oluşacak hasarı önlemek ve oyun elemanlarının kontrolünü sağlamanın yerel yönetimlerin görevi olduğuna dikkat çekmektedir. Coşkun (2015,s.154)'un Ankara ilinde yapmış olduğu incelemede, parkların belediye görevlileri tarafından düzenli aralıklarla denetlendiği ifade edilmektedir. Denetim açısından gerekli özenin gösterilmesi, oyun elamanlarının ve oyun alanının güvenliğini yükseltecektir.

Yapılan araştırmada, oyun elemanlarının çoğunluğunun plastik ve metal malzemeden oluştuğu tespit edilmektedir. Fakat oyun elemanların ahşap ve zemininin kum olmasl, genel olarak kabul görmekte ve uygulanmaktadır (bkz. Akkülah ve Güngör, 2009,s.11). Araştırmada görüldüğü üzere, oyun alanlarının zemini genellikle kauçuktan yapılmıştır. Benzer durum Aydın ilinde de tespit edilmektedir (Samur ve Kızıltepe, 2018,s.36). Kauçuk olan zemin çocuğun düşmesi durumunda ciddi yaralanmaları azaltmakta ve yürümeyi kolaylaştırmaktadır (Aklıbaşında, Tırnakçı ve Özhancı, 2018,s.67). Ancak zemini kauçuk olan bu alanların taşlarla çevrili olması, engelli çocuklar için uygun değildir. Bu durum engelli çocukların parka ve oyun elemanlarına ulaşımını kısıtlanmaktadır. Oyun elemanlarının ve zemin malzemelerin, bazı olumsuzluklar sıralansa da (Aklıbaşında, Tırnakçı ve Özhancı, 2018,s.67) kum gibi doğal olması çocuğun gelişimi açısından önemlidir. Coşkun (2015,s.76-77; 154), oyun elemanlarının satın alınması ve yapımı konusunda gerçekleştirilen ihalelerde, standartlara uyma konusunda bir şartın bulunmadığı, TSE'nin belirlediği standartlar gibi (TSE EN-1176 gibi) kriterlerin, bir zorunluluk olarak dikkate alınması gerekliliğine dikkat çekmektedir. Kuşçuoğlu (2013: 42) çocuk oyun alanlarında zemin drenajının iyi olmasına, su biriktirmemesine, fiziksel koşullara göre zemin malzemesinin niteliğinin iyi olmasına ve zamanla bozulmaması gerekliliğine vurgu yapmaktadır. Doğal malzeme ve zemini olan alanlar, çocuklar için de daha çekici ve sağlıklı hala gelmektedir. Pepe ve Kırçık (2005,s.1144), oyun oynaması süresi ne kadar artar ise oyun değerinin o kadar artacağını belirtmiştir. Özalp vd. (2012,s.21)'in Artvin ilinde yapmış olduğu incelemede, çocuk oyunlarının zemininin mıcır, beton, çakıl gibi malzemelerden tespit etmiştir. Yapmış olduğumuz araştırmada ise Giresun ilinin oyun alanlarının zeminini daha uygun olduğu söylenebilmektedir. 


\section{Sonuç ve Öneriler}

Çocuklar, yaşı gereği oyun oynamaya gereksinim duymaktadır. Oyun alanları, çocuklar için özel ve gerekli alanlardır. Bu alanların oluşturulması, yerel yönetim birimlerinin görev ve sorumluluğundadır. Bu araştırmada Giresun merkez ilçede bulunan oyun alanları, nicelik ve nitelik açısından incelenmektedir. Mahalle bazında oyun alanları incelendiğinde, kentleşmesini sürdüren yeni olarak nitelendirilecek mahallelerde, artan nüfusla birlikte oyun alanı miktarının artığı, çocuk başına düşen alanın 9.3 ile $1.5 \mathrm{~m}^{2}$ arasında değişkenlik gösterdiği, fakat oyun alanının bulunmadığı mahallerin varlığı tespit edilmektedir.

Çocukların sosyalleşebildikleri fiziki yerler oyun alanlarıdır. Bunun için oyun parklarının sayısının çoğaltılmasının yanı sıra oyun elemanlarının niteliğinin artırılması gerekmektedir. Oyun alanlarının genişletilmesinde mevcut yapılaşmadan kaynaklı boş alanların bulunmaması, Esenler ve Adapazarı Belediyeleri'nin uygulanmasında görüldüğü sokakların oyun alanına dönüştürülmesiyle giderilebilmektedir (http://www.adapazari.bel.tr/haber/6/1355/cocuk-haklari-sokagi-coskuylaacildi, https://esenler.bel.tr/projeler/cocuk-sokagi/, 11. 02. 2020). Ayrıca bilhassa 0-3 yaş grubunun genel özellikleri dikkate alınarak ve bazı örnek çalışmalardan (0-3 Yaş Oyun parkı Fikir Rehberi, https://issuu.com/bernardvanleerfoundation/docs/oyun_park fikir_rehberi tr issuu, 11. 02. 2020) hareketle, çocuk oyun alanları ve elamanlarının gözden geçirilmesi önem arz etmektedir. Diğer taraftan oyun alanları, engelli çocuklar için de bir sosyalleşme aracıdır. Engelli bireylerin genel toplumsal yaşama entegrasyonunun oyun alanlarından başlaması daha yararlı olabilecektir.

Oyun alanlarının zemini ve oyun elemanları yerleştirilirken fiziki ve iklimsel koşullara da dikkat edilmesi önemli bulunmaktadır.

Oyun alanlarında her yaş grubu çocuğun serbestçe oynayamadığı durumlar tespit edilmiştir. Bu eksiklilerin belediyeler tarafından giderilmesi yararlı olcaktır. Toplumun dezavantajlı grubunda yer alan çocukların en çok zaman geçirdikleri bu alanların güvenliği, gerekli ihtiyaçlarını giderebileceği alanların arttırılması yönünde çalışmalara gereksinim duyulmaktadır. Çocukların oyun alanlarında oynama süreleri, ebeveynlere ayrılmış yerlerin fiziki şartlarının iyileştirilmesi ile artış gösterebilecektir. 
Çocuklara, parklardaki oyun elemanının tasarımını yapabileceği ortamın sunulması, ilgili sürece katılımını sağlayabilcektir. Gerçekleştirilecek iş birliği ile çocukların oyun üretkenliği sağlanabilecektir. Bu şekilde geleneksel oyunların unutulması durumunun da ortadan kalkacağı düşünülmektedir.

Parkların iyileştirilmesinde yerel yönetimlere ve çocuklara önemli görevler düşmektedir. Çocukların haklarını daha iyi kullanabilmeleri adına gitmeleri gereken yetkili mercilerle rahatlkkla iletişim kurabilmelidirler. Bu hususta yerel yönetimlerin desteği önemli olacaktır.

Çocuklar için ayrılan bu alanların çoğunluğunun standart olarak yapılması, her çocuğun farklı yetenek ve becerilerini göz ardı etmektedir. Çocuğun zaman geçirdiği bu alanların ihtiyaçlarına karşılık vermemesi, eylemsel olarak oyuna karşı itici güç oluşturabilmektedir. Bununla birlikte çocuğun sosyalleşmesini olumsuz etkileyebilmektedir. Oyun açısından çekici olmayan parkların başka bir itici gücü de, çocukların sanal ortamlara daha fazla dahil olma yönünde ortaya çıkabilmektedir. Dolayısıyla oyun için ayrılan bu alanlar kullanılmamakla birlikte boş kalmaya mahkûm bırakılmaktadır. Oyun alanlarının oluşturulmasında çocukların fikirlerinin alınması, bu alanları daha fazla cazip hale getirebilecektir (katılım konusunda Çanakkale deneyimi için bkz. Başaran Uysal, 2015). Oyun alanlarının oluşturulmasında görüşleri alınan çocuklar, kendilerine ait bir mekânı daha fazla benimseyebilecektir. Bu durum yerel birim ve çocuklar arasındaki iş birliğini beraberinde getirebilecektir. Bu sayede yerel birimin bir parçası olan çocuklar, oyun elemanlarının bakım ve onarımında doğrudan rol üstlenebileceklerdir. Diğer taraftan çocukların, yaşadığı alanda katılım sağlamaları, gelecekte etkin bir yurttaş olmalarında katkı sağlayabilecektir. Fikirleri ile katılım sağlayan çocuklar, öz benliklerini de güçlendirmiş olabilecektir. Çocuklar, oyun alanlarında var oldukça fiziksel, zihinsel vs. gibi daha birçok yönde kendi gelişimlerine katkı sağlayabilecektir. Bununla birlikte sanal ortamda oynadıkları oyunların etkisi azalabilecektir. Parklarda oynayan çocuklar, bireyselleşmenin tersine toplumsal yardımlaşmayı ve toplu fikir üretmeyi öğrenebilecektir.

Yerel yönetim birimleri, oyun alanlarının ve oyun elemanlarının yapimında ve konumlandırılmasında, niceliği kadar niteliğine de önem vermesi gerekmektedir. Oyun elemanlarının bakımının da düzenli olarak yapılması, çocukların oyun dönemlerini daha verimli şekilde geçirmelerine katkı sağlayacaktır. 
Tüm bu ifade edilenlerin yanında, özgün bir ismi bulunmayan oyun parklarının isimlendirilmesi, okul bahçelerinde yer verildiği gözlemlenen geleneksel oyunların dikkate alınması, oyun elemanlarının plastik ve metal malzemelerden yapılmasıyla da ilişkili olarak geniş yapraklı ağaçların yanında tente gibi yapay gölgelendirme araçlarının kullanılması, oyun alanlarının ayrıca ışıklandırılması önemli görülmektedir. Diğer taraftan özellikle kış aylarında ve yağmurlu havalarda oyun oynama ihtiyacını karşılayacak alanlara da ihtiyaç duyulduğu görülmektedir. 


\title{
EXTENDED ABSTRACT
}

\section{Children and Playgrounds in the Urban Area: A Study in the Case of Giresun Central District}

\author{
Levent Memiş -Sila Gülcan \\ Giresun University
}

A specific stage of life is described as childhood, and the ones belonging to that stage as child. Although the childhood stage is approached differently, it is accepted as 0-18 age range. In fact, period itself mentioned also has substages (such as 0-3, 4-6, 7-15 ages) and the physical and biological needs of kids in these stages differ. Within this development period, one of the most important tools of a kid is games and toys. As well as contributing both in physical and mental development, these tools are also important in terms of social development. Games, which is the correspondence of all activities that a kid willingly participates in without any external pressure, are a need that comes after the kids' physiological development (Çakirer-Özservet, 2018a, p.91). While the instrumental place of the games from early ages contributes in child's socialization, development and learning, it has a very important role in making children healthy and successful individuals. It is also important to mention that games are not just a tool participating in a kid's life. Games can become a tool, with its different types (digital or manual), for adult's leisure, a part of education or a helping hand for urban management. According to 2019 data, there are 19.212.345 children between the ages $0-14$ in Turkey. Meaning the $23,1 \%$ of the population (83.154.997) is made up of children.

For games, it gains importance in urban fields where most of the children also finds a correspondence for their lives. While towns must respond to the expectances of communities such as women, old, disabled, rich, poor, it also has to fulfil the needs of children for them reach a better life standard. Within this context, playgrounds are places where kids can develop themselves socially. Especially functional, safe and sound playgrounds that find correspondence in public spaces are playing a big role in this matter. In the contrary case, playgrounds that cannot fulfil the needs of a child, not well in 
condition and not being used are a potential danger that cannot be denied. At this point, municipalities, which are primarily in charge of urban area management, has big responsibilities.

In the sense of what's mentioned, main point of this study is to examine the level at which the child reciprocates in local politics through children's playgrounds. This examination is carried out quantitatively in the context of adequacy of playgrounds on a neighbourhood basis, qualitatively within the scope of play elements in the playgrounds, and in the means of Giresun central district. It was benefited from TUIK (Turkish Statistical Institute) in order to obtain the child population on a neighbourhood basis, from Giresun Municipality in order to obtain quantitative data about playgrounds of neighbourhoods within this sense, and from "Children's Playgrounds Data Acquisition Form" which was developed based on relevant literature in order to obtain qualitative status of the play elements.

According to the data acquired from the research there are 50 active playgrounds/parks in Giresun central district. Not all of the parks have information about their establishment years, information about 23 of them can be obtained. It is seen that 14 of them were built after the year of 2014, too.

It is emphasized that a playground should be not less than $250 \mathrm{~m}^{2}$ (Akt. Özalp vd., 2012). Four of the parks (north of 26 Evler, Tozlu Street, Inonu Avenue and Mollaoglu Street) examined in this sense are below the relevant criteria. Along with the parks that are built on fill areas, play elements' space are extended and variability has increased. However, these playgrounds are areas that appeal to the whole of the province that can be reached via vehicle rather than being a neighbourhood park. The functionality of playgrounds in terms of interaction is mostly established on spaces that exist at neighbourhood level. When this is taken into consideration, playgrounds being at a neighbourhood gain importance.

In the examination carried out, it is determined that there are no such thing as variability in types of play elements in playgrounds except for three of them (Botanik Garden, 15 July Sports Complex and Youth Centre). It is seen that swing and slides are commonly used in these playgrounds. Games are also a great supporter of the mental development of a kid asides from being a physical activity. Therefore, it is accepted that variability in play elements has positive effect in terms of the creativity of a child. 
On the other side, in the examination, it is determined that disabled individuals are not taken into consideration both in building process of the playgrounds and the choice of play elements. However, within the scope of Child Friendly Town project, there is a park includedwhich is devoted to disabled kids in the action plan prepared for Giresun Municipality. Bringing this arrangement that is given place in the planning process to life, will not only encourage the disabled individuals to participate in these playgrounds but will increase their integration to the social life.

When the playgrounds are examined according to the age group, there is only a single so called playground (in the youth centre), apart from the swings and slides that can correspond to the needs of children aged between 0-3 based on their peculiar characteristics. If we are to look at the parks in neighbourhoods, the existence of playgrounds where children of 0 3 age group can play games safely, and the play elements are out of question.

When the play elements in the playgrounds are considered generally in terms of functionality, safety and maintenance, functionality is only midlevel. Especially, the distance between swing and slide being so short possesses danger for children of small ages.

In terms of maintenance of game elements; the presence of abrasions, breaks, rust, and breaks are observed. These cases appear to be in most of the play elements that are in broad daylight. The maintenance and safety of play elements in the park should be taken into consideration as a whole.

As for the safety of parks, being surrounded by barricades comes into importance. Although there are barriers surrounding the vast majority of the parks examined in the research, the absence of a door or a barrier that will prevent the rapid exit at the points that provide entry-exit to the playground is a security threat. Alongside this case, it is beneficial for a child's development that the park is in a place exposed to sunlight all day long. In the research carried out, nearly all of the parks are exposed to sunlight all day long except for the 2 of them. On the other side, material used for the ground where the play elements are and it being surrounded by rocks is decreasing some risks but it also limits the functionality of the park.

It is determined that majority of the play elements examined in the research are made out of plastic and metal materials. However, it is generally approved and applied that the play elements should be wooden and the 
floor should be sand. At this point, highlighting wood and sand factors in children playgrounds comes into importance.

\section{Kaynakça / References}

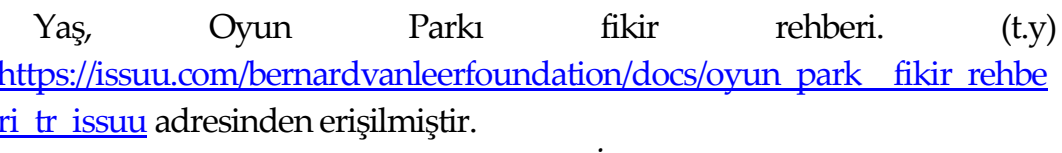

Acar, H. E. (2017). Çocuk oyun alanlarnnda güvenlik: İstanbul Fatih ilçesi örneği. Yayımlanmamış yüksek lisans tezi, Namık Kemal Üniversitesi, Tekirdağ.

Akkoyunlu E., K. (2014). Kent ve kentli haklarl, Ankara: Türkiye ve Orta Doğu Amme İdaresi Enstitüsü.

Akkülah, A. T., ve Güngör, S. (2009). Oyun alanları güvenlik standartlarının araştırılması ve Nene Hatun Parkı örneğinde irdelenmesi. Selçuk Tarım Bilimleri Dergisi, 23(47), 11-13

Aklıbaşında, M., Tırnakçı, A., ve Özhancı, E. (2018). Çocuk oyun alanlarının önemi ve tasarım kriterlerinin Nevşehir kenti örneğinde irdelenmesi. İnönü Üniversitesi Sanat ve Tasarm Dergisi, 8 (17), 66-67.

Bahtiyar Karadeniz, C. (2016): Ordu şehir merkezinde çocuk oyun alanlarının dağılı̧̧ ve yeterliliği, Geçmişten Günümüze Şehir ve Çocuk II (Ed. O. Köse), Samsun: Canik Belediyesi Kültür Yayınlanı, 1197-1209

Ballığlu, S. (2015). Aydın kenti örneğinde gençlik parkı çocuk oyun alanımın yeterliliği ve tasarm ilkeleri yönünden incelenmesi. Yayımlanmamış yüksek lisans tezi, Karadeniz Teknik Üniversitesi, Trabzon.

Bernard Van Leer. (t.y). Kent95 Başlangıç kiti.https://bernardvanleer.org/app/uploads/2018/05/BvLF-KENT95Baslangic-Kiti.pdf adresinden erişilmiştir.

Bulut, Z., ve Kılıçaslan, Ç. (2009). An important principle to encourage self-reliance to child: playground safety. Artvin Çoruh Üniversitesi Orman Fakültesi Dergisi, $10(1), 81$.

Coşkun, E. B. (2015). Çocuk oyun alan elemanlarmın standartlar üzerine bir inceleme. Yayımlanmamış yüksek lisans tezi, Ankara Üniversitesi, Ankara.

Çakırer-Özservet, Y. (2018a). Kent havası çocuğu özgür kılar mı?. Çocuk Üzerine Araşttrmalar, (Ed. G. Uludağ ve M. Altunbay), Ankara: Astana Yayınları

Çakırer-Özservet, Y. (2018b). Sokakları çocuk kokan şehirlere özlemle..., 10 Şubat 2020 tarihinde https://www.academia.edu/38131752/Sokaklar\%C4\%B1 c ocuk kokan s ehirlere o zlemle.pdf adresinden erişildi. 
Çetin, G. (2003). Üsküdar İlçesi'ndeki çocuk oyun alanlarmın yeterlilik ve kalite açısından incelenmesi. Yayımlanmamış doktora tezi, İstanbul Teknik üniversitesi, İstanbul.

Çocuk Hakları Sokağı Coşkuyla Açıldı. (t.y). Adapazarı Belediyesi.http://www.adapazari.bel.tr/haber/6/1355/cocuk-haklari-sokagicoskuyla-acildi adresinden erişilmiştir.

Demir, Z., Kırkık Aydemir, P. ve Önem, H. (2015). Kentsel yeşil alanların Akçakoca örneğinde ulaşılabilirlik bakımından irdelenmesi. Düzce Üniversitesi Bilim ve Teknoloji Dergisi, 3, 272-282.

Duman, G., ve Koçak, N. (2013). Çocuk oyun alanlarının biçimsel özellikleri açısından değerlendirilmesi: Konya İli örneği. Türk Ĕ̆itim Bilimleri Dergisi, 11(1), 6-8

Erkartal, Ö. E., (2015). Çocuk oyun alanlarını tasarlamak: Zorlu center çocuk parkı örneği Mimarlık Tasarım Kültür Sanat Dergisi, 12, 99.

Ermiyagil, M. S. A., ve Gürçınar, C. S. (2015). Kentsel mekânın gelişiminde çocuk oyun alanlarının rolü: KKTC'de yeni kent Gönyeli örneği. İdealkent, 6(17), 12-45.

Esenler Belediyesi. (t.y).Çocuk sokağıhtttps://esenler.bel.tr/projeler/cocuk-sokagi/ adresinden erişilmiştir.

Gürbüz, D. Ö. (2017). Yapısal ve işlevsel açıdan Afyonkarahisar çocuk oyunları. Yayımlanmamış yüksek lisans tezi, Ankara: Hacettepe Üniversitesi.

Jansson, M. (2008). Children's perspectives on public playgrounds in two Swedish communities. Children Youth and Environments, 18(2), 88-109

Karasu, M. A. (2009). Kente karşı suç, Ankara: Savaş Yayınevi.

Keos. (t.). Giresun Belediyesi Haritalar.http://keos.giresun.bel.tr:85/keos/ adresinden erişilmiştir.

Koçan, N., ve Çorbacı, Ö. L. (t. y.). Uşak İli Kemal Öz Mahallesi'nde Çocuk Oyun Alanlarının Niteliğinin CBS İle Irdelenmesi. 05 Şubat 2020 tarihinde http:/uzalcbs.org/wp-content/uploads/2016/11/2012 002.pdf adresinden erişildi.

Kuşuluoğlu, D. D. (2013). İstanbul Kadıköy ilçesindeki çocuk oyun alanlarının nitel ve nicel açıdan değerlendirilmesi. Yayımlanmamış Doktora Tezi, İstanbul: İstanbul teknik üniversitesi.

Mamur Işıkçı, Y. (2019). Kamu yönetimi ve çocuk ilişkisi: çocuk hakları bağlamında bir değerlendirme. (Ed. Y. Mamur Işıkçı), Kamu Yönetimi ve Çocuk, Ankara: Astana Yayınları, Ankara.

Mutlu, A. (2010). Kentli hakları ve Türkiye. Konya: Çizgi Kitapevi. 
Onur, B. (2010). Oyuncaklı dünya. Ankara: İmge Kitapevi.

Özalp Yavuz, A., Muhacir Arslan, S., Ada, Ö., ve Akkaya, U. (2012). Artvin kenti çocuk oyun alanlarının yeterlilik açısından irdelenmesi. Ĕ̆gitim Odă̆ında Artvin Sempozyumu, 05 Şubat 2020 tarihinde https://docplayer.biz.tr/14569142-Artvin-kenti-cocuk-oyun-alanlarininyeterlilik-acisindan-irdelenmesi.html adresinden erişildi.

Pepe, K., ve Kazan-Kırçık, Ş. (2005). Burdur ili belediye sınırları içindeki çocuk oyun alanları ve parklarının donanım çeşitliliğinin araştırılması. I. Burdur Sempozyumu, 05 Şubat 2020 tarihinde https://docplayer.biz.tr/8901475-Burdurili-belediye-sinirlari-icindeki-cocuk-oyun-alanlari-ve-parklarinin-donanimcesitliliginin-arastirilmasi.html adresinden erişildi.

Samur, A. Ö., ve Kızıltepe, G. İ. (2018). Aydın ilindeki çocuk oyun alanlarının incelenmesi. Sosyal Bilimler Araştırma Dergisi, 7 (1), 36.

Şimşek, S. (2010). Imar hukuku. Ankara: Ümit Ofset Matbaacılık.

Şişman, E. E ve Özyavuz, M. (2010). Çocuk oyun alanlarının dağılımı ve kullanım yeterliliği: Tekirdağ örneği, Tekirdağ Ziraat Fakültesi Dergisi, 7, 21.

Tan, E. (2019). Play the city: Oyun mekânlarının arşiteknotiği şehrin zindanları ve ejderhaları (D\&D), Şehir \& Toplum, 14, 95-103.

TÜIK (2019). Giresun mahalle bazında çocuk sayısı.

Türkan, E. E., ve Önder, S. (2011). Balıkesir kenti çocuk oyun alanlarının irdelenmesi. Tekirdă̆ Ziraat Fakültesi Dergisi, 8 (3), 75-78

Uysal, A. B. (2015). Çocuk oyun alanlarının geliştirilmesinde bir yerel katılım deneyimi. Megaron, 10(3), 430

Yılmaz, S., ve Bulut, Z. (2002). Kentsel mekanlarda çocuk oyun alanları planlama ve tasarım ilkeleri. Atatürk Üniversitesi Ziraat Fakültesi Dergisi, 33 (3), 345-351.

\section{Kaynakça Bilgisi / Citation Information}

Memiş, L. ve Gülcan, S.(2020).Kentsel alanda çocuk ve çocuk oyun alanları: Giresun merkez ilçe örneğinde bir araştırma. OPUSUluslararası Toplum Araştırmaları Dergisi, 16(27), 633-671. DOI: 10.26466/opus.692731 